NOTES ON THE PORCUPINES OF THE MALAY PENINSULA AND ARCHIPELAGO

\author{
BI+ \\ MARCLS WARD LYON, JR.

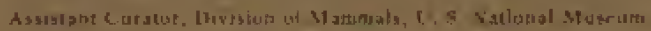

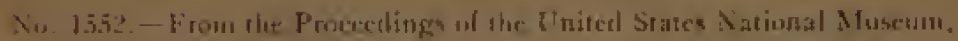

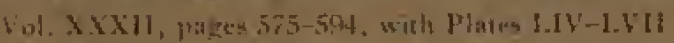

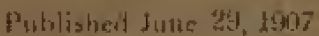

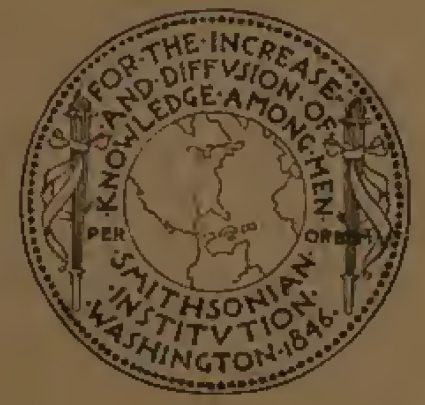

Washington

Goverment Priting Office:

1007 



\section{NOTES ON THE PORCUPINES OF THE MALAY \\ PENINSULA AND ARCHIPELAGO}

$\mathrm{Br}$

MARCUS WARD LYON, JR.

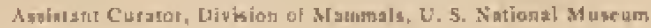

No, 1552.-From the Procedings of the United States Nalioual Museum,

Fol, XXXI1, pages 575-5!4, with Plates L.IV-LVIJ

Published dune 29, 1007

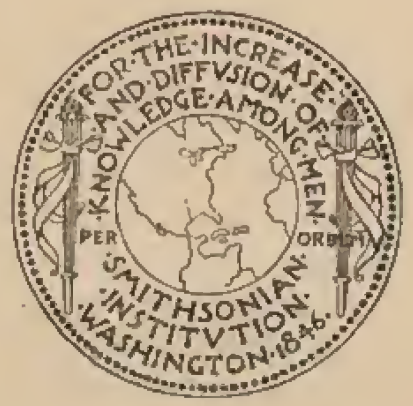

Washington

Government Printing Office 1007 



\section{NOTES ON THE PORCUPINES OF 'THL MALAY PLNINSULA AND ARCHIPELAGO.}

By Mareus Ward Lron, Jr., Assintmit Curator, Division Mammals, $U . S$. Vational Muscum

The followitg notes are of a preliminary nature only, and are written with the idat of briaging together in one place a consideration of the systmatic nanes of the Malayon porcupines and the characters by which these animals are arranged into nutural groups, both of which considerations are at present seattered through various puhlieations. The main fratures bronght out in this paper are the divisjon of the old World porenpines into two subfanilies; the revival of Cuvier's name feantion as a genus for the short-tailed Malayan porcupines; the revival of Linnetsis's name Mystric brachara as the proper specilic designation of the short-tailed porcupine of the Malay Peninsulat: the deseription of a new genus and species of short-tailed porcupine collerted in northern Sumatra hy Dr. W. L. A bhott in 1906; and the description of a new species of Athermes from Pulo Terutan, ofl the west colat of the Malay l'eninsula. The presence of two dis1jut tyenera of long-tailed porenpines it the Maluyan region cunsed considenable confusion in the use of numes by the older writers, but Jentink, in 1s94, clearly pointed ont the true status of these groups. Seba was well acyluanted with three of the four generat of Old World porcupines that have been recognized up to the prosent time, and it was largely from his descriptions and plates that Linnas ia the tenth edition of the Systema Natura bised three names of the Old World porenpines, which at that time were regarded as so many distinct species and not as distinct grenerie types as they have since been considered.

It is to rogretted that more examples of the typieal grenus Hystrix have not been arailable in the preparation of these nofes for deter-

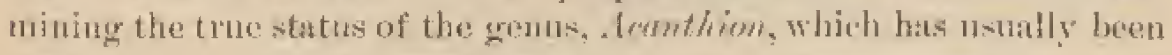

a Notes Ixyden Musum, XVI, 18\%, [. 205.

Proceedings U. S. National Museum, Vol, XXXII-NO. 1552.

PTow, N. M, rol, xxxil-0 $\bar{i}-37$ 
considerod syonymons with part of Hystrin. However, the material at lisud shows very considerable dillerences between $/ / y s r^{2} x$ proper and Acanthon, whish will be pointed ont further on. With regard to some of the species in the various genera of Malayan porcupines. I have not seen a sufficiont number of specinens to detemine the characters satisfactorily. Where several forms of one group, each form occupying a definite and isolated geographic area, have been named I have made use of the nanes bestowed upon them even if their specific claracters are not clear, believing this plan better than to place them under one specific name, for naterial is as lacking to show their identity ats it is to show their distinctness.

The list of works to which reference has been made in preparing these notes will be found under the synonymy of the different species of referred to in footnotes. The specimens on which these notes are trased are listed in the table of measurements, page 593. They represent forty individuals from Malaya, thirty-three skins with skulls, two odd skulls, and tive skejetons. All but three of these specimens were collected hy Dr. W. L. Abbott, and have been presented by him to the U.S. National Musenu.

KEY TO THE GENERA OF MAIAYAN JQILCPISFS.

a Tail short, lese than one-fourth length of head and borly; eatal hairs terminating mostly in hollow masnle-like structures, molan rootless, Buntal vertebre?

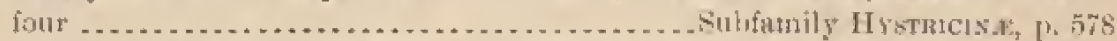

b Torsal profile of skull aretued, nasals extending back to level of lachrymals, and

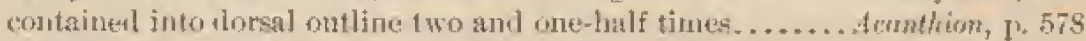

bu Dorsal profile of skull searly straight, masts extending back to level of anterior borker of infratbital formmen, contained into dorat outline three and one-

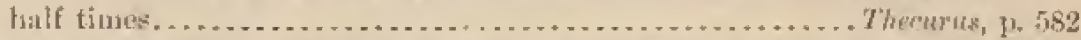

aa Tail long, wne-third to one-half length of beal and holy, terminating in a tuit of molifial bristles, molar rooted, sacral vertehre tlired.

Subfamily A tüвенш $x, 1,584$

c Fach caudal sctale subtended by three hairs, terminal bristes alternatety

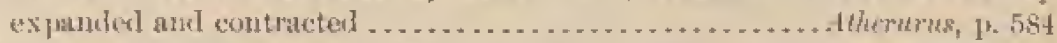

ce Wach caudal seale subtended by a singlo hair, terminu bristles of uniform

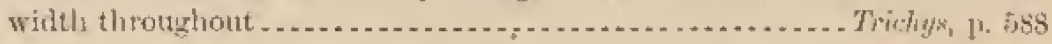

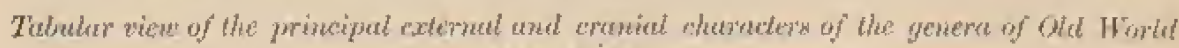
porcetyines.

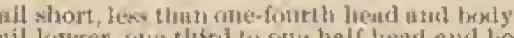

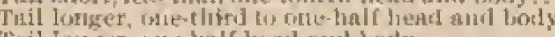

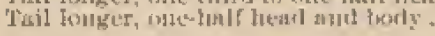

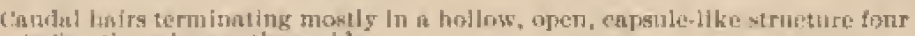

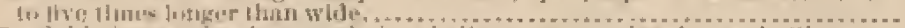

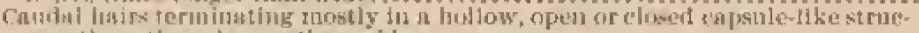

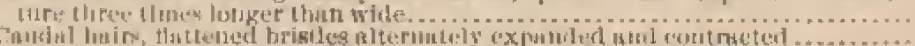

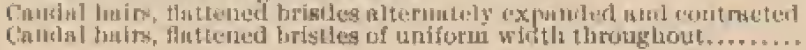

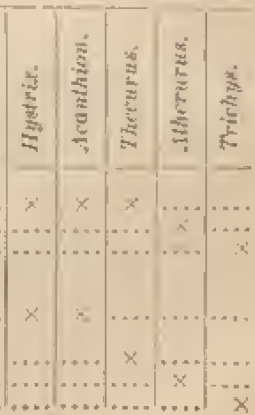




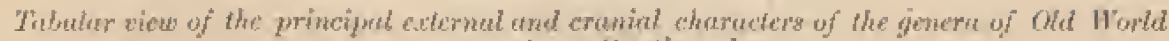
proveriurs-Continuesl.

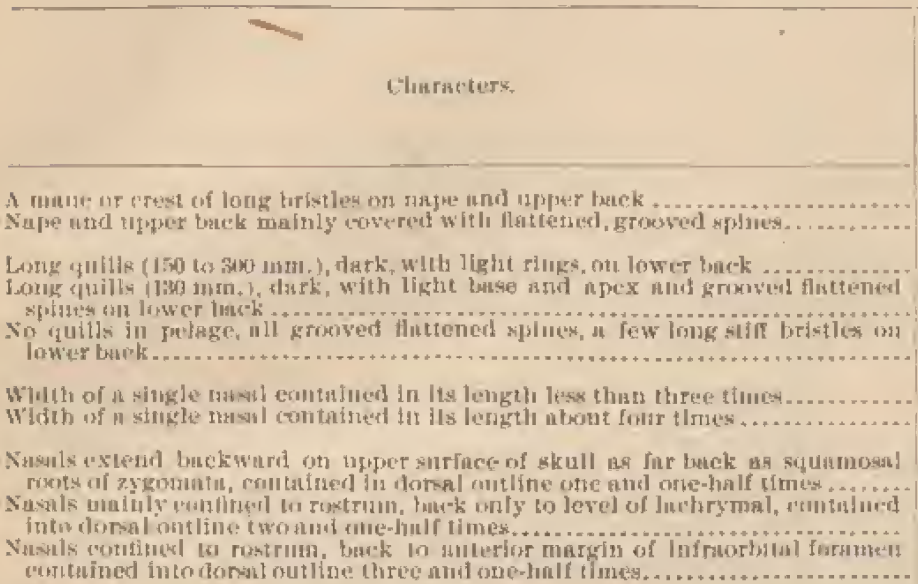

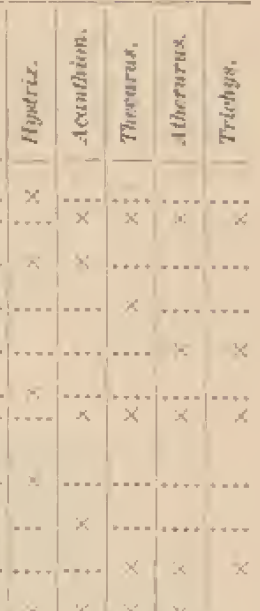

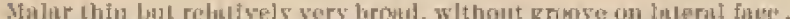

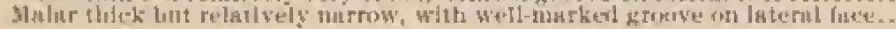

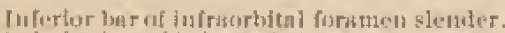

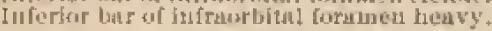

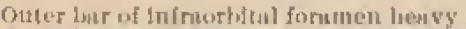

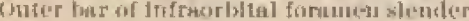

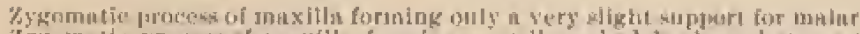

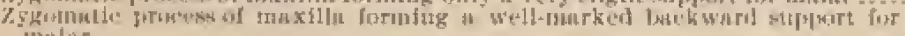
IInine.

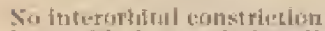

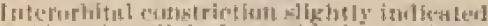

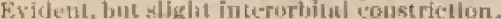

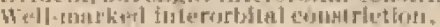

A 1 ingrews

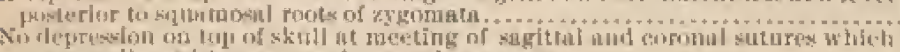

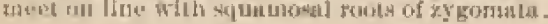

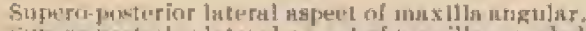

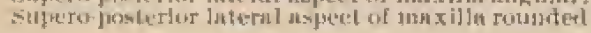

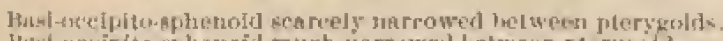

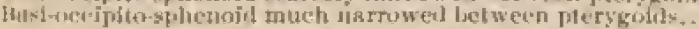

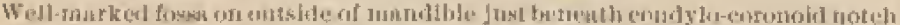

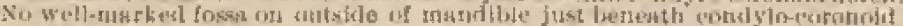
Intwh.

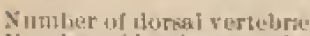

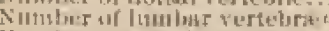

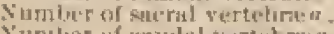

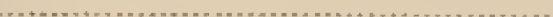

S

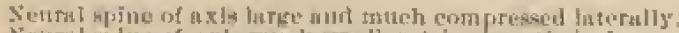

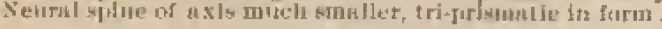

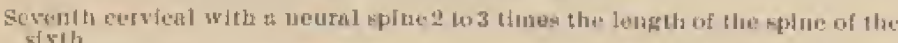

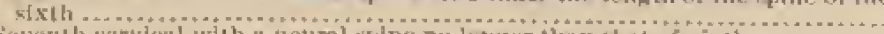

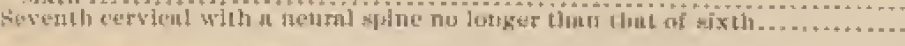

Niniber af sterinl sersuentits.

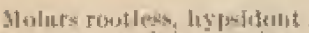

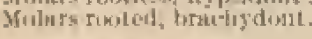

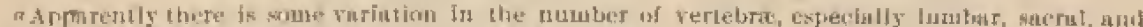

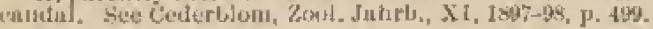


Sublanily HŸTHICINA.

The subfanily Hystricine is chamcterized among the Hystricide hy laving a short external tail, withont a well-malked hatless scaly portion between its base and apex, in thwing the ternimal hat of the tuil modilied into hollow capsule-like structures, mostly open at the ends, in the possession of well-dereloped quills on the batek, in haviug four sacral rertebra, and rootless, hypsidont molars. It contans three genera: Ilystrix (not considered in these notos, bertuse not found in the Malayan sulnegion), Aanthion, page 5is, and Theowres, pare artio.

ACANTHION F. Cuvier.

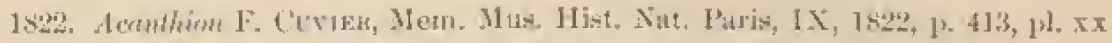
bis, lips. 3,4 .

Type.-Acanthon jawaniem, from Java.

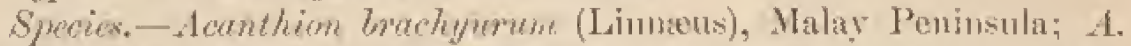
lompicumlum (Marsien), Sumatru; A. jawanicum F'. Cuvier, Java; A. crassisyinis (Günther), Borneo.

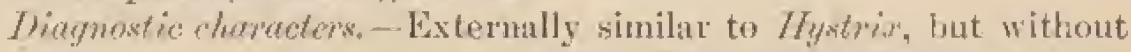
a crest or mane and puills not so long. Cranialy it differs in having mud stualler nasils, exteuding back only as fur as on a level with the latelrymal bones, and contaned into the dorsal outline two and onehalf times, instead of extending as far buck as the squanosal roots of the zygomata and contined into the dorsal ontline one and one-hulf times, as in /ystrix. No depression on upper surface of skull at the union of sagitul and coronal sutures. Molats rontess.

Litemal characters.-Size large: head and body about 600 to 700 mm.; tail short, about one-tifth length of heal and body. Upper. surfitee of hend clothed with stifl, rounded, brintly hitrs, those on the nupe considerahly elonguted, hut not forming the well-defined mane

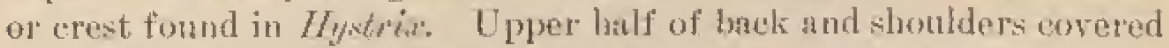
with Hittened spines, tsistlly each with dowal and sometimes ventral grooves. Ahout the middle of the back these spines replaced by large heary anills, light in color, with a single dark band near the middle or toward the bast side of the middle. 'The quills vary in length from 50 to $250 \mathrm{~mm}$, and are longest toward the middle of the lack, becoming yuite short near the rump, where, howerel, they are still quills and bear no resenblance to the flattened spines found on the ipper half of the back. On the base of the tuil the ruills brome loiger again. The distal portion of the tail is clothed with poruliar hairs. (Plate LVII, fig. 1.) The basal portion of ench (Lo to 15 am.) is yuite hair-like, but it abruptly expands out into a bollow cylinder. like an efongated mapsule, about 5 mus. wide and abunt fonr to fiva times as long. Nearly always the ends of these cupsule-like hairs are open, but racly the sides of the capsule are prolonged to meet in at 
pointed apex. The sides of head, the unter parts, and the legs ato in gentut covered with soft ilattened spires similar to those int the upper buik, but slorter and not so stiff.

Shetem. - The mat fertures of the skull of the genus feanthion hate previously leen pointed out. The relative size and shape of the skull and of its varions prorts are efenrly shown in tig. 5. Plates LIV, LV, ard $\mathrm{L}$ VI, so that no detailod deseription is necessity here. The vertebal formula is $\mathrm{Cr}, 7, \mathrm{D}, 14, \mathrm{~L} .5,5 . \pm$, Cd. about 15. The axis bears a lioge rectangulaz netral spine, projecting bukward as a thin plate of bone, laterally compressed. (Plate LVI1, fig. 11.) 'The surenth eervical bears a long pointed neural spine, about three times the length of the nental spine in front of it, and about half the size of the first dorsal spine. 'The lumbar vertebre lave large rectangubo lateral processes, directed forward. (Plate LVII, fig. 12.) The first and half of the somend sacril vertebre serve for the attalument of the ilia. 'The presternun is relatively long, and its expanded part relatizely nurow. 'The limb hones are relatively short and hetry, the scapule wide.

\section{ACANTHION BRACHYURUM (Linnasus).}

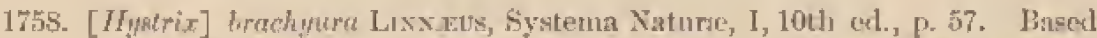
on EFat, Rerum Nat. Thesair., I, p. 81, pl. 1.11, fig, 1, from Jaya, Sumatra, and from Malacea. In view of Seba's natue Hystrix mulecensis and his

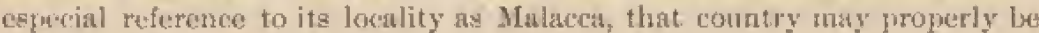
comsidered the type-locality.

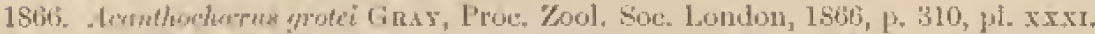

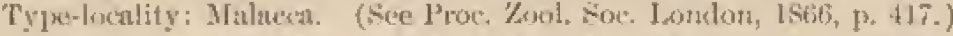

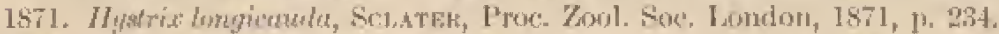

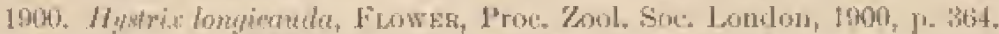

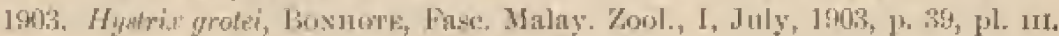

Distribution.-Mality Peuninsula.

Dingmostic chardeders. - Apparently the largest of the Malayan species. Greatest length of skull, 135 to $150 \mathrm{~mm}$.

Contri.-Upper half of back, top of head, underparts, and legs and feet, an indetinite blackish brown or brownis] black; is dirty wlite or dirty bufl pateh on throat, partly extended apward and backward alongr the side of neck. This is followed by a blackish brown collar and this in turn by at lighter collar, but this latter is not always woll marked. 'The quills are dirty white or dirty buff in color, each with a bard of blackish brown 20 to 30 mm. wite at or below the unddle.

Siall. - The only peenliarity of the skull of this species apparently is its large size total length of an old atdult being $150 \mathrm{~mm}$, and of at young adult about $140 \mathrm{~mm}$.

Mersintments, - See table, page 593.

Specimens carmined. - One old fenale from Chanpang, Tenasserim; two udults and two young from Trong, Lower sian. 


\section{ACANTHION LONGICAUDUM (Marsden).}

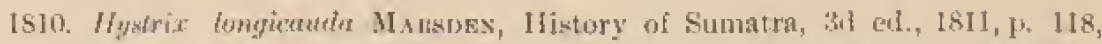

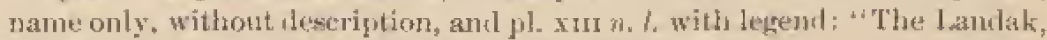

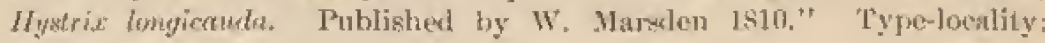
Simatra.

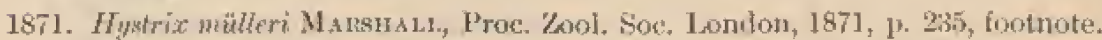

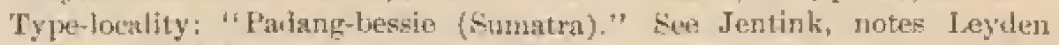
Musetum, I, 1879, 1. 81.

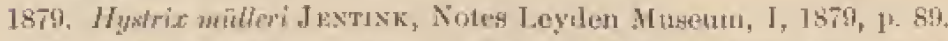

1888. đranthion mülleri, Jextixk, Cat. Syst. Mammiferes, Mus. Hist. Nat. Paypbiss, XJI, p. 104.

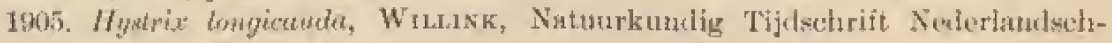
Jutie, LXY, 1\%. 260 .

1905. Hyxtrix longinaula, Sorshitons, Zool. Jaturb, Syst. Geogr. Btol, XXIII, p. 113.

\section{Distribution. - Sumatra.}

Dhagnostic characters. - Sinilar to Acanthon brachyemom, but apparently slightly smaller; with less conspicuous throat collas.

Colon:- $\mathrm{A}+$ in $A$. brachyum, but in the single available specimen the light throat collar very poorly defined and the sides of hody are lighter in color, owing to the spines having lighter bases than in A. brachyoum.

Skull.-Widently smaller than that of A. brochyurum. Jentink th gives the total length of the skull of an old male ats $135 \mathrm{~mm}$. 'The skull of at young mate in the U. S. National Musenu mensures $108 \mathrm{~mm}$. total length, against $110 \mathrm{~mm}$. total length in a skull of the same age, as judged by the teeth, from the Malay Peninsula.

Mrasurements. - See table. page 543.

Specimens extmined. - One, a young male, from Aru Bay, Sumatra.

Remarkix. - Jentink" revords Acanthion mälleri and scanthom jowtnicum from Sumatra, Tanjong Morawa. No description of them is given, but it is to be supposed that they difier", as pointed out by Jentink a in 1879, manly in size-in which case there are two distinct forms of Acanthion in Sumatra. That Jentink did not bave a specimen of Thecurus, is evident from the fact that the smaller of his species, A. jamanioum, has a skull length of $118 \mathrm{~mm}$., while the skull length of Thecurus is scarcely more than $100 \mathrm{~mm}$.

\section{ACANTHION JAVANICUM F. Cuvier.}

1822. A[canthion] Jawicun F. Cuvifn, Mem. Mus. Hist. Nat. Faris, IX, 1822, 1. 431, pl. $\mathrm{xx}$ bis, figs, 3, 4. Type-locality: Javi.

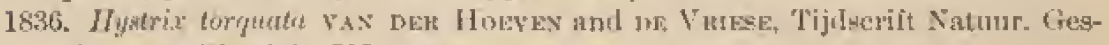
chied. en Physial, III, 1836, P. 110.

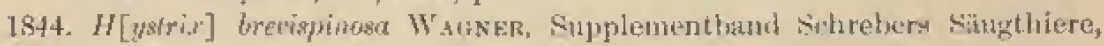
IV,, 20.

"Notes Ieyden Museum, L, 1879, p. 94.

${ }^{b}$ Idem, XI, 1889, 11, 28. 


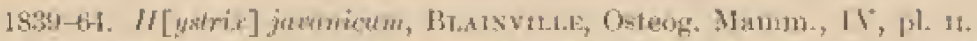

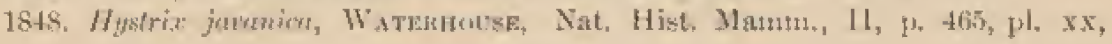
fig. 4 .

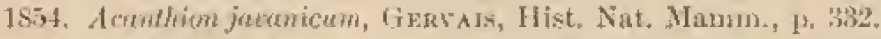

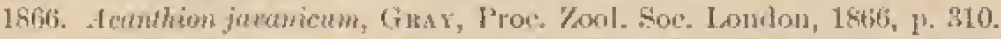

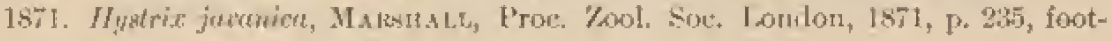
note.

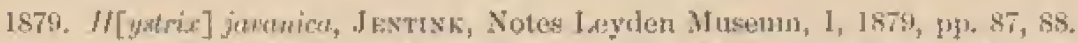

1888. Lenulion jetanirum, Inxtš, Cat. Syst Mammifires Mus. Hist. Nat. Pays-tas, XII, p. 10,

1905. IIstrix jatanica, WiLdsk, Natuurkundig Nerlertardsch-Indië, LXV. p. 266 .

Distrilution.-Javit.

Remarlis, -. I latre seen no specimens of this species. There is at skeleton of an old indivislual in the National Musem, labeled "IIystrin jamica; Java." It wus purchased from it dealer several years ago, and probably labeled "Java" because it had been identified as Hystrix jacaniea. The total length of the skull meatsures $195 \mathrm{~mm}$. It is distinetly smalter than skulk of like age from the Malay Peninsula, but at the same time nuch larger than the 118 mon, given by Jentink" as the total length of a . Tavan Acanthim skull.

\section{- ACANTHION CRASSISPINIS (Günther),}

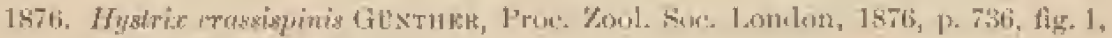
1).

1803. Hystrix crassigpinis, Hose, Jammaly of Bormeo, p. 60.

1505. Hystri, crussispinis, Wtodask, Natutrkundig Tijdsehrift Nederlandseh; Tndië, LXV, p. 26e\%

\section{Distribution.-Borneo.}

Diandostic charteters. Chize small; skull, total length 110 mm. Spines thick, egual twice the ditmeter of an incisol, longitndinally grooved on their upper surfaces.

Remarks. - I have seen no specimens of this species, but Güuther's origiaal deseription slows that it is a well-marked form. His plate woukl indicate that it is a lighter (browner) colored animal than either Acanthion bradyurm or longicandum. His measmements show it to be a smaller animal tban .1. javanicmon.

In M/ammals of Bumeo" "Lose records IJstrio mïlleri.Jentink, also from Borneo, saying: "This porcupine is like Hystrie crussispinis, but distinguished from it hy its black belly and somewhat dilferent caudal quills. The skull also differs, but the size of the animals are much the same." In all probability 1. oressispinis bas a dark belly, atthough there is nothing in the original description to show that the betly is light or dark. It is thus impossible to say how Hose's second species of short-tailed poreupines from Borneo differs from Aconthon 
crassispinis. It is possible that two ol more species of the genus Acanthion are found on Borneo; but at present there is nothing in the literature to show this fact satisfutorily or to indicate what their diaracters are.

THECURUS, new gerus.

Family,-Hystrieida, subfanily Hystricine.

Type.-Theorus sumatra, new species. (Description on page 58\%.)

Spicien, - The type speeies is the only known one in the genus so fin as known.

Diagmostic characters. - Extermally like a small Acanthim, but eapsule-like ends of catdal hiris, stualler and relatively shorter, often closed at the ends (Plate LVII, fig. 2), quills smaller, and replaced on lower rump by grooved spines similar to those on upper bick. Cranially very similar to the genus Athermus, lut brain-case relatively wider, rostrum martower, and no well-matred fossa on outer side of mandible just beneath condylo-coronoid noteh; nolars rootless.

Erternal characters.-About half the size of Acmithen, to which it has a striking resemblunce, but it has no bristly hairs on the lend or neck, hut merely soft, flattened spines. The llattened spines extend farther down the back than they do in Acanthion and are moge conspicuously grooved, and they are also found on the lower buck and rump instead of the short quills of Acththom. "The large heary quills occupy wbout the third fourth of the back. They are unch less namerous and shorter than those of Acanthion, the largest not exceeding $150 \mathrm{~mm}$. These quils are dark in cotor, with a light lmse and apex. A very few long stitf bristles are interspersed among the quills. Some short quils are found on the tase of the tail, while the terminal portion of that organ is covered with peculiar modilind lais's, but the capsules ate relatively much shorter and a great man more of them are closed at the apex-drawn out to a point. (Plate LVJJ, fig. - .) The sides of the bead, the underparts, and the logs, are in general elothed witl rather soft, flattened, groored spines.

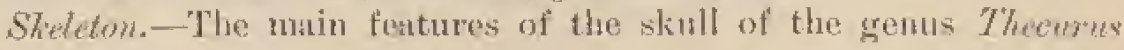
have previously lees pointed out. "The relative size and shape of the skull and its various parts are clearly shown in fig. 1. Plates LIV, LV, and $\mathrm{LV1}$, so that no detailed description is lere necessary. "The vertebral formula is: Cr. 7, D. 14, L. 5, S. 4, C1. 17. Althongh the skeleton of Therurus as a wbole, aside from the skull, is in general strikingly like that of Acmthiom, yet in one or two points it is quite different. Instead of having a large, laterally compressed nental spine on the axis, that vertebra bears a relatively short, wi-prismatic spine, not compressed laterally any more than it is antero-posteriorly. (Plate LVII, fig. 9.) The seventh cervical vertebra in Them spine. The long neural spiue or the seventi cervical seen in Aan- 
thion has been shifted butaward in Theours and is found on the first dorsil rertebra; the very long neural spine on the first domal of

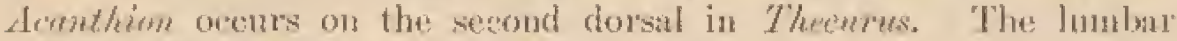
vertebra (Plate IA VI, tig. 10) in Theomme hive large rectaygular lateral processes, directed anteriorly much as in Acanthion, but the processes are rather more slender. 'The tirst and one-half of the socond sacml vertelyme serve for the attachment of the ilia. 'The presternm is relatively shorter in $7 /$ woms than in foanthim atul the expanded purt is relatively wider. The limb bones ane relatively short and heavy, proportioned as they are in Acanthion, but the anteriorly projecting "knee" at about the middle of the tibia is more pronounced. The seapula is somewhat wider, in proportion to size, in Thenmes than in famthiom. It is almost identical in size and shape to the sc:upula of themuths.

THECURUS SUMATRAE, new species.

Type. - Skin and skull of atult male, Cat. No. 143432, [.S.X.M., collected at Aru lay, east coast of Sumatra, Jamury 17, 190h, by Dr. W. L. Abbott. Original No. 4637 .

Distribution.-Known only from the vienity of Aru [3ay, Sumatri.

Diaynoxtio characters. - The same as given for the genus above.

Color:-General color on top of head and anturior half of back, much like a dark dab of hidgwas, specked, especially on top of notk and town the sides with the dirty white tips of the spines. Sides of heal and neck and underparts drab, conspicuonsly specked with the dirty white tips of the spines. Under side of neck dirty white or creum-huth, crossed by a drab collar 25 to $30 \mathrm{~mm}$. wide. The feet and legs are darkened almost to Ridgway's seal brown. The quils ate blackish, with dirty whitish tips of 20 to 251110 . Syines on the lower back blackisll with short (about 5 mm.) light-colored tips.

Stull and treth.-The chaticters of the skull have already been destribed. The skulls as a whole slow a great deal of individual Fariation in respect to size, comparative wiclth of skull, and lengrth of nasals. (Seb tatble of measurements, p. 593.) "The teeth show equal vatution in size, No. 14343t laving the length of mper foothrow $19.5 \mathrm{~mm}$. and No. 143435, with teeth worn to the sante extent, 17.2 mm. Weat produces very striking effects on the teotli; reontrant angles seen in the young and in the young adults are entirely lost in old individuals, and judging by the teoth atono one night easily consicler foumg and wyed nublts to belong to different generta.

Mensarmants.- External measurements. (See table, p. 598.) Crunial metsurements of the type: Basal length, 92.3 $11 \mathrm{~m}$; bisilar bength, 85; condy k-busal length, 99.4; grentest longth, 105; upper length, 103.7: palatat length, 51.3; zygomatic !readth, 56; distance between outer matrins of axternal anditory mentus, 42.8; interorbitul constric- 
tion, 31.8; grestest length of 11 astal, 29.6; width of both nasis torether, 15; maxillary toothrow (alveoli), 19.3; mandibular toothrow (alveoli), 19.5.

Specimens exmined. - Nine skins with skulls, one odd skull, and one skeleton, all from Aru Buy, east const of Sumatia.

Remarks. - Thecartes smmatme is a very distinct form of pormpine and apparently bears little resemblance to other described genern or species. Externally it closely resembles a small Acanthion, white "ranialy it has so many points in common with Athomos that there are almost no chathcters, aside from roolless molars, by which the two muy be generienlly separated. In many respects it is an intermediate link between founthion and thenoms.

In 1879a Doctor Gruther described a small porcupine from the island of Paragua, Philippine Islands, under the name of $/ / y, r \% x$ pumila. 1 have seen no specimens of this species nor any figmes of it, but the original description and the detailed measurenents given lead me to believe that //ystrits pumila is closely related to Theremes sumatre and may possibly be a second species of that genus. Whatever the relationship, Doctor Gunther"s masmements indiate that

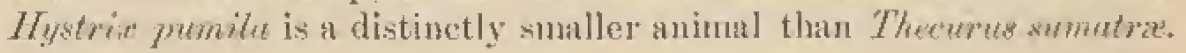

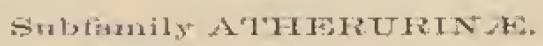

The subfamily Atherurinte is distinguished among the Hytricide in the possession of anther long external tuil, with a well-marked somly portion between its base and apex, which is terminated by a long tuft of modified hairs ot bristles; in not having well-developed quills on the back, but merely stifi grooved spines; in luxing three sacul vertebre and rooted, brachydont molars. It contuins two genera: Atherurtex, page 584, and 7richys, page 5ss.

\section{ATHERURUS F. CUVIEr.}

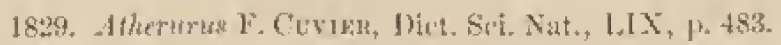

Type.-Hystrix macomom Linneus, from Malacot."

Spevies. (In Malityan reginn) Atherumes macrmms (Linnatus), from Malucea; A. syomistions Miller, from Pulo dor; and A. temataus, new (page 587) Pulo 'Terutau.

Dirgmostic charteters.- $-\Lambda$ small sized porenpine, without quills, with a large souly tail, each soale subtended by three lairs, and terminated by a tuft of bristles, nostly llattened and altirnately contracted and expanded one to five times. (Plate LVII, fig. 3.) Skull

"Ann. Mag. Nat. Hist., JV, 187!, p. 10t?.

u See Jentink, Noteg Leyden Museum, XVI, 1894, p, 207, Lyon, P'roc. Biol. Soe. Washington, XIX, Decenber 31, 1966, p. 199, and flomas, Proe. Biol. Soc. Washington, XX, p. 66, June 12,1907 . 
in nany respects like that of Thecurtes, but relatively matrower and with less abrupt rostrun, and witl a well marked fossin on side of mandible beneath the condylo-coronoid notch and with rooted molars. Differs from the skull of Thichys in the absence of postorbital processes, and in having distinctly heaviel maluts.

Eartemal characters. - Size small, a little less that of 77 cowrus, tril long, about one third head and body. Entire upper parts and sides of body and bise of tail covered with heny: somewhat Hattened spines, with a large groove on their dorsal aspert, and at shallow groose on their nulerside at the base. The spines ate lomgest on the lower buck, rump, and base of tail where they als athont 75 mu. long. No guils proper are foumd on this poreupine, but interspersed anong the flattened, grooved spines on the lower hack are a fow lounded stiti hristles, somewhat quill-like at the hise, having a length of lon to 195 mnd. The liend. underparts, and the leuss, are wotherd with soft, flat spines. The basal fourth of the tail is covered with spines, like those of the lower back; the middle two-tourths are covered with soules, cach of which is subtended by threes short lutis, a median stifl, long one. with a shorter liner one on either side; the teruinal fouth of the tatil is matuly eorered with peculiar thatemed hollow batris and sone ordinary bristles. Each of these peuliar hat's begrins with a hajlike base, lut soon expands into a small, narow, hollow, llattened rapsule, followed by a short hati-like spane and then anothey that, holtow capsule, sone hairs having as many as five such expatisions. These hatrs alwy terminate in an expansion with a long drawn-ont apex. (1)ate LVII, hig. 3.)

Sheleton. - The main fentures of the skull of the genus Atherame have previously been pointed out. The relative size and shape of the skull and of its various parts are elenty shown in hig. 2. Plates I.IV, LV, and I,VI, so that no detailed desoription is bere necessary. The

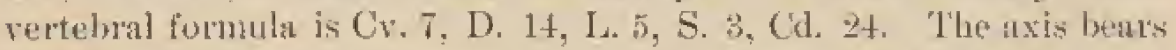
a large neumal spine liattened from side to side, similar to that formal in Aeanthion. lut subtriangular in ontline and directed backwarl at a sharper angle. (Phate LVII, fig. 7.) The seventh cervical has a short neural spine, like that of the sixth, and the long spine of the seventis shen in Acunthion las been shifted buckward to the first dorsil, ax in Thecems. 'The Jumhat vertobro have rather na low lateral purocesses, directed forward at a more acute angle than they are in the two preceding genern, and the ends of the processes are some what entarged. (Plate LVII, fig. 8.) Only thee vertebrite compose the sacrum in Whemres, and the first alone serves for the attabment of the ilia. The presternum is relatively short, sud its expunded portion relatively narrow. The bumerns is relatively more slender in therumes than it is in santhon or Theow the deltoid ridgre is less promi- 
nent, and the olecrinon process of the ulna is shorter. The fommr, tihis, and fibula are groportioned albont as they are in the two prateding genera, but the metatarsals and phatuges are relatively tonger. The scapula of Athorums is broad.

\section{ATHERURUS MACROURUS (LinnaUs).}

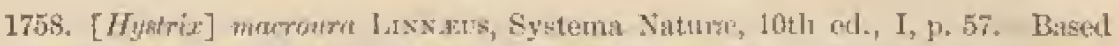
on Sens, Rerum Nat. Theteaur, I, p. 84, pl. Lit, fig. 1. Lowality not known, other than Bast Inclies."

1801. Ilystriz macrouru, Sitsw, Gen. Zool., II, I't. 1, p. 9, pl. cxxil.

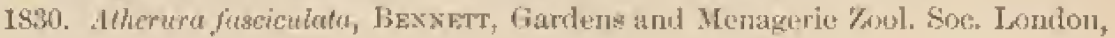
P1. $175-178$.

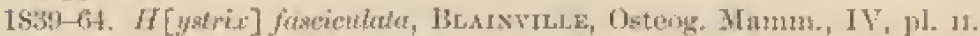

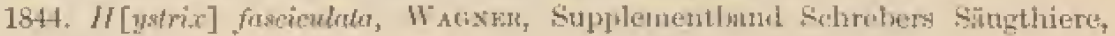
IV, $13+23$.

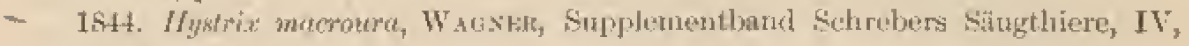
pl. chaxx,

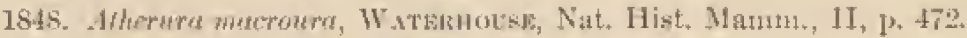

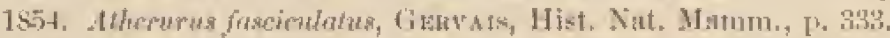

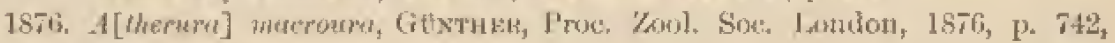
fig. A.

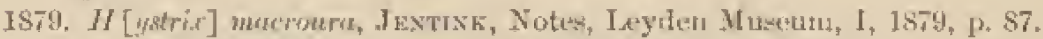

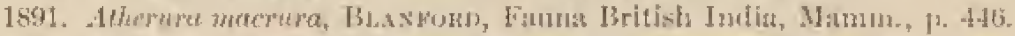

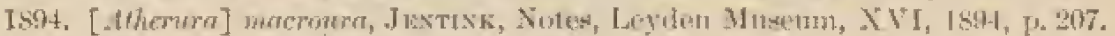

1905. Ahesmorn macroura, WrLLixk, Natumrkundig Tijdsehrift Nederlandsch lndivi, $\mathrm{L} . \mathrm{NV}$, p. $26 \mathrm{~T}$.

Distribution.-Malay Peninsuln, Burma, and porlaps varions Maliyan Islauds.

Color, - General eflect of top of head, upper back, and of feet, Ridgway's drab, rather dark. The heavier spines are a blarkiat

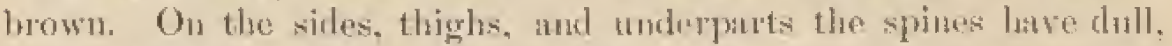
dirty whitish hases and subterminal apical bands, with a drabor dyatbgray batnd botween them, and a vory slight dowberay ajex. The chin and uppel throat ale paticularly" light, as w+ll as an ill-defined Inand across the chest. The light color of the bises and of the subterminal rings of the spines show to a maked extent on the sides and muderparts. The tuft of bristles at end of tail vary from dirty whitisis to a dirty remurift.

Mersurements. - See tuble, pagre 593.

Spectincur extmined.-Four, from Trong, Lower Siam.

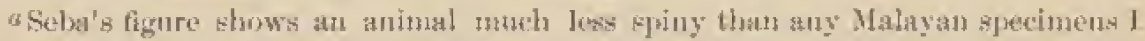
have seen. The deseription of the tail does not agme with apermers of his gom

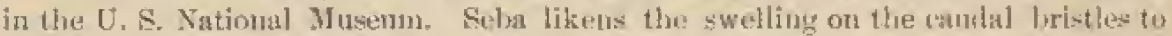
grains of rise intosed in an envelope. In the spemen at hand etch bristle, while hollow, is flat and alternately widened and eontrasted laterally in one plane only,

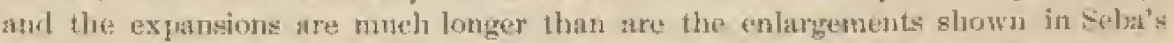
figure. It is barely possible that the animal usually designated as fthefumes macroma (Linnous) is roally an undeseriled species. At least it would so appenr if seba's account is at all accurate. 


\section{ATHERURUS ZYGOMATICUS Miller.}

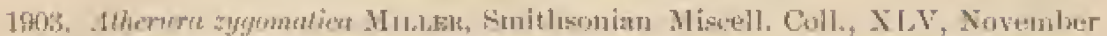

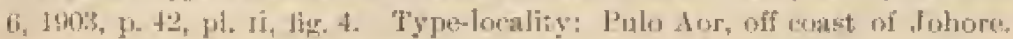

Lisfributiom,-Kinown only from Pulo Aor, off cosst of Johore.

Typo-Adult femalo, skin und skull, Cat. No. 112+29, U.S.N.M., collectorl on Plalo Aor, otl contst of Johore, June 6, 1901, by Dr. W. L. Abbont, Original No, 18199.

Diugnatio chanaters.-Lilie Athomms manmums, but color darker, and zygoma shortel und deeper, under side of malar bone with a conspicuons tooth-like process directed hatkward, lachrymal bone moch smaller, scaredy appestring on dorsal aspect of skull.

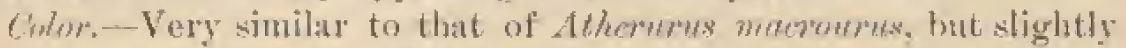
darker, esperially along the sides, due to the light area of the spines leing less in eridence.

Shall and teath.-In general, the skull is very similar to that of Atherume mecrouras of the Malay l'eninsula, but in size it is somewhat sumbler and differs conspictiously in regard to the lachrymal bones and the zygomata.

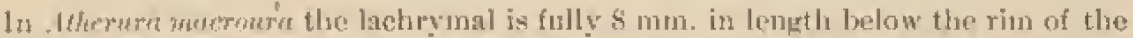
orloit, while ahove it extends forward as a triangle of bone at lestst "s mins. long, and

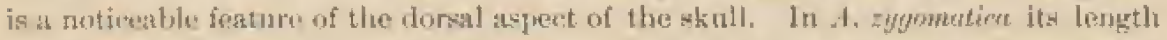
bulow rim of orbit is 11sultly shout 5 tnin., * * * while the forward extension is oiten olusolete and never large tnumgh to the more than barely visilue when the fikull is

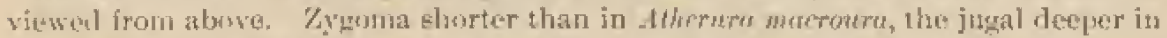
prunwrtun to its length, more abruply aucaved aboves and its lower conton invurialily * * * broken ly a strongly developen moneavity beneath pasterior jugal suture, this conemity terminating anteriorly on the pusterior upper surface of a well-marker? tooth-like projection.

Measurmenta, - For a comparison of the cranial measurements of the trpe, with the type of Atherurus termates and with an alult fentale from 'lyoug. Lower siam, see page 5s. For measurements of the series, see tahle, page 549.

Specimens edomiond. - Seven: all from Pulo Aor.

ATHERURUS TERUTAUS, new species.

Type-Skin and skull of adtult male, Cat. No. 123971, U.S.N.M.,

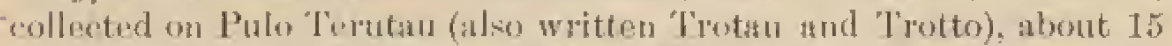
geographical uniles west of the Maiay Peninsula, where the one hundredth meridian east of Grenwioh euts the west const of the Malay Peniusula, April 10, 1944, by Dr. W. I. Abhott. Origrinal No. 3228.

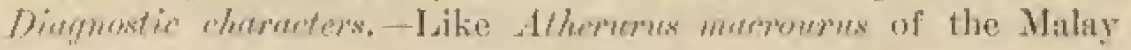
Prninsula, but smaller. witla shorter tail; bachryal bone mach smaller. sutedy appeariar on the dorsal aspect of the skull. It

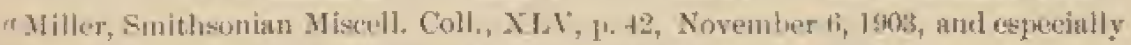
I'late ]l, tigs, 4 and in, where the above characters are well shown. 
resembles A. zyyomaticus from Pulo $\mathrm{AOr}$ in its suall lachrymal, hut lacks the heavy zyoma and the step-like plojection on its inferior border. Caudal bristles shorter thas in eithes A. macomrs or 1. zygomaticus, and with the single (in the other species these are usually thee to five on $n$ bristle) expansion relatively narower and longer. The bristles, however, have a worn appearance, which might account for this difference.

Color. - The color of Alhemus temines so closely resembles that of 1. Eyyomatius that no detsiled desciption is necessary.

shall and teeth. - In general, similar to those of Athemorus macmu urus, but distinctly snaller, rostrum and nasals relutively sborter, constriction letween the orbits more prononnced, depression on top of skull greater: lawhymal bone much smaller, surcely any of it appearing on the dorsal aspect of the skull; in this respect resembling the skull of A. zygmatices: zygomata of the same form as in 4 . macrmmms: andital lulle, smaller. Teeth of same form as in A. maerem urus, but smaller:

Medrutinents. - See table, page 593. Cranial measurements of the type: Greatest length, 92.2 mm. (94.3, 99); basal lengtl, 82.2 (82.6, 87.t): basilar length, $76.1(75.6,80.5)$; condylo-basal length, 87.8 (S9), 94.2); palatal length, 4.7 (15.5, 47.6$)$; greatest lengrth of nasil, 22 (25.9, 26.3); zygomatic breadth, 45.8 (45.9, 47.5); least interorbita] breadth, 24.5 (2ti.1, 28.4); maxillary toothrow (alveoli), 15.7 (17.1, 17. 2$)$; mandibular toothrow (alveoli), $17.3(17.9,18.8)$.

Sprimens exuminel. One, the type.

Remarks, - Although lout out specimen of Athermme terutans is known, its peculiarities areso well murked that its specifiedistiuctness frum A. moreromens and A. sygomaticus can not be doubted. It possosses the peculiar lachrymul bones of A. zygomations, hut its zygomatu ate exactly as they gre in A. mavemes from the manland.

\section{TRICHYS Giinther.}

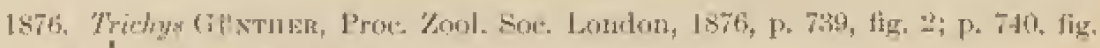

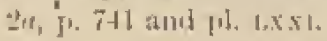

Type- Trichys lipura, from Borneo.

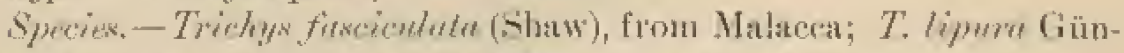
ther. from Borneo; 7. macrolis Miller, from Sumatra.

Didfuntic chardeters. $\mathrm{A}$ suall porenpine externally resemblingr Atherums lout with a relativety longer tail, each scale of which is subtended by a single hair ats with the brash at end of tail composed of taxt grooved bristles, with parallel sides. (Plate LVIl, fig. 4.) Skull sunall, different from that of Alhemos in possesing distinct postorbital

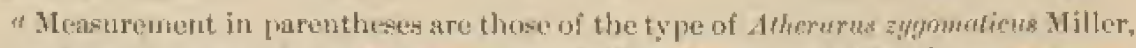
frum f'uto Aot, and of an alult female, Cat. No. 84t3, U.S. N.M., of A. mecrourus, from Trong, lower siam, 
proceseses, a mort slender and pronounced rostrum, aygomata nore converging anteriorly, and a heary grooved malar of nearly uniform widh throughout its length, which is subtonded by th consideratsle back wat axtension of the maxillary portion of the zygoma. Molars footed.

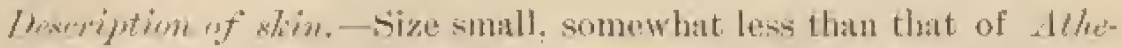
rum, tail relatively longer. Uppej parts and sides of lody covered with solnes more flat and less stiff than in Athymas. grooved both ahove and below. of about the same length (25 to 30 inm.) all over the back. Interspersed anong thesn ate a very few stifl bristles, abont 75 min. long. The head, underparts, and the legs are covered with softer, shorter bristles. The extreme base of the tail is crered with spines like those on the back. 'I'he grentest portion of the tail is coveted with woll-dotined soles, auth subtemded ly a single

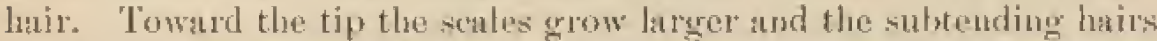
leconne longer (abont 100 mm.), flat, hollow bristles of miform width theseghout their "xtent. (Plate LNII, lig. 4.)

Shetem. The antion fortums of the skull of the genus Trichys have previously beon pointed out. The rolative size and shape of the skull and of its rarions parts are clenrly shown in tig. 3. Plates $1.1 \mathrm{~V}, 1 . \mathrm{V}$, ant IVI, so no detailed description is here necessaly. The rertebrat

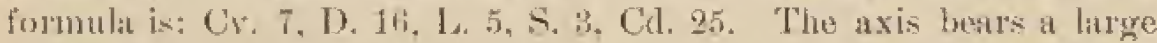
laterally-compressed nemal process, strongly curved and bent batkward. (Pate LVII, fig. 5.) The neumal spine of the serenth ecrvical

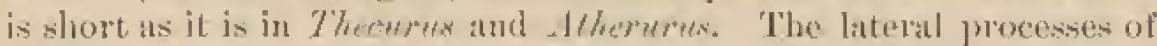
the lumbar vertebro are ruther slender, carved, and diceted forward, and with a somewhat pointed apex, (Plate LVII. fig. 6.) "The suentum is of fortu similan to that of Atherwos; it contains three vertebre, and to the first of these the ilia are attached. The prestermum is relatively short, and with a relatively narrow anterior expansion. 'The humerts and the bones of the foresm are proportioned as they are in the

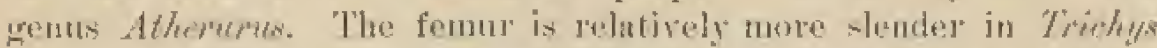
than in the ofher genera, and the metatarsals and phatanges are some-

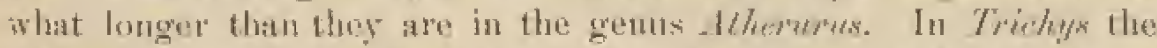
seapula is nuch uarower than in the other geners, and its anterior border is strourgly rounded off.

\section{TRICHYS FASCICULATA (Shaw), n}

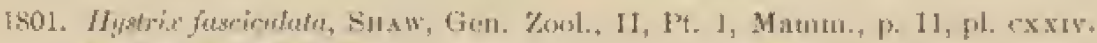
'Tymentorility: Malsu'ca.

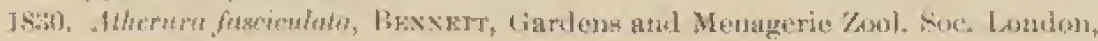
pp. 175-178.

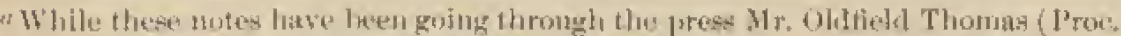

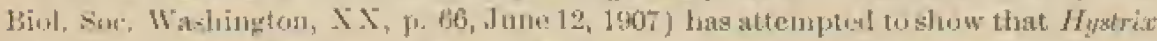

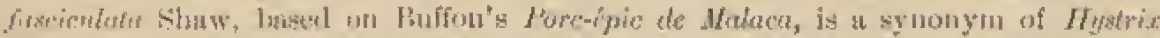

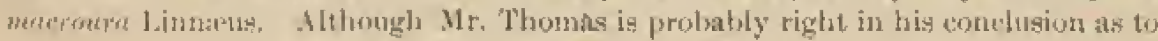




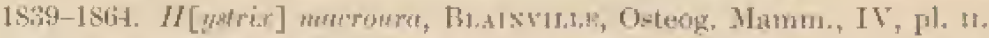

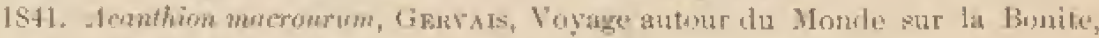
1) $3,60-63$, Atlas, HI. $x 1$.

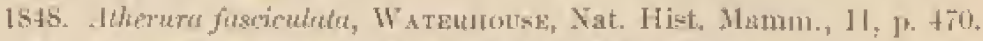

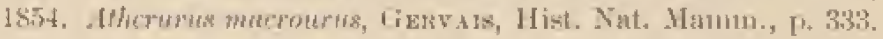

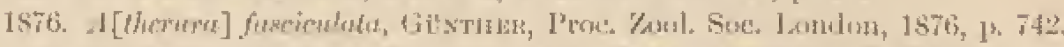

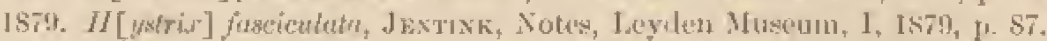

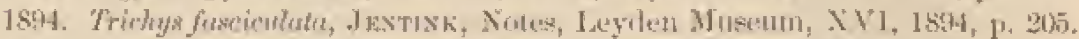

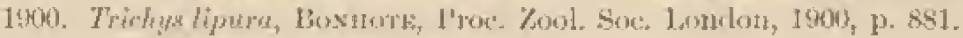

Distribution.-Malay Peninsulat.

R math. - I have seen no specinens of this species which hats usinally been considered symonymous with the Bormean Trichys lipura. berause of the general distincthess of mammals of the Nalay Peninsula and those from Bormeo, that view does not appear prolyblide and, looth animals having heen named, those nanes are here retaned. It is jossible, on the other hand, that the Sumatran Trichys masotis naty be very close to the Malay Peninsula animal.

TRICHYS I.IPURA Gunther.

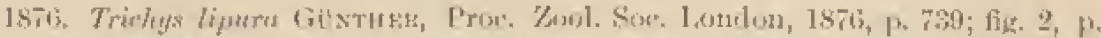

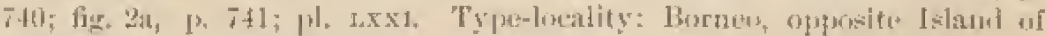

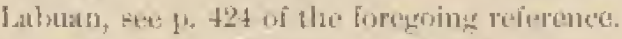

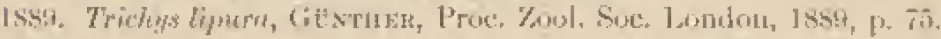

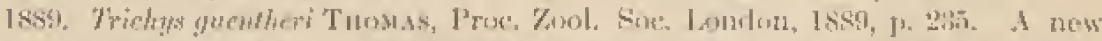

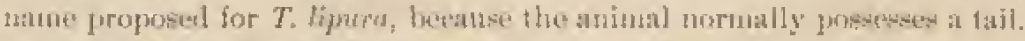

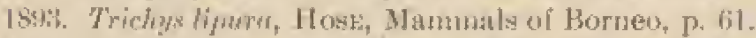

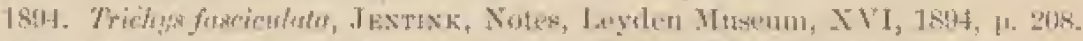

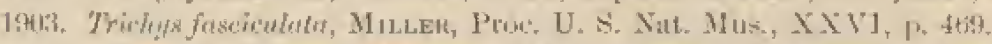

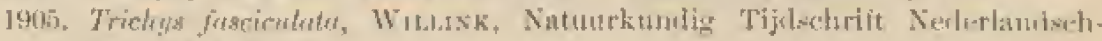

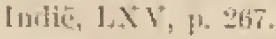

\section{Distribution.- borneo.}

Ghos- General color atwove a sort of drat-brown. The bases of the spines are whitish, which is the gement color of the underpats owing to allisence of drab-brown tips of the spines. On the sithes the eolor graduatly passes from the almost eomplete drab-brown of the uppere parts to the whitish of the belly.

Shull and teeth. - These are well figured by Gïnther." and mead no detaifed description here.

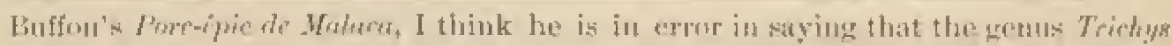

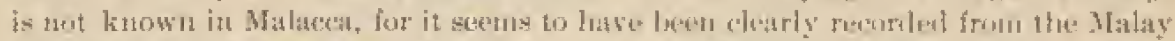

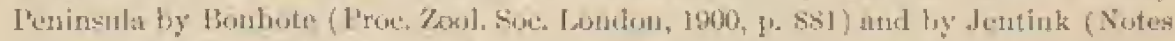

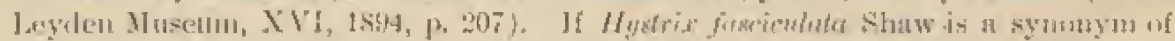

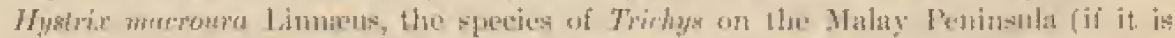

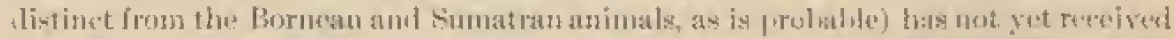

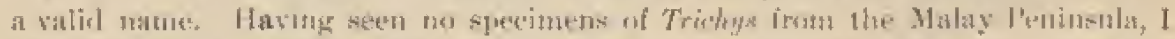

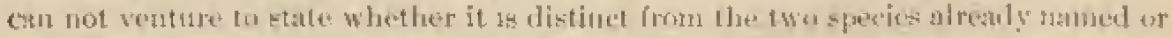

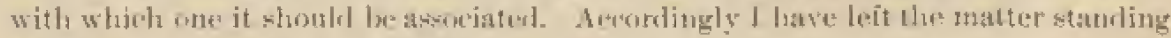
as arizinally written, lut will this explangtion.

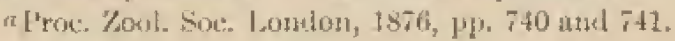


Heasuremen/s, - Ste table, puge 593.

Specimms ramined. - T"wo, skin and skull of nearly adult male from Momnt Salikan, Borneo, and the skeleton of an adult from British North Borneo.

\section{TRICHYS MACROTIS Miller.}

1903. Trichys mecrolis Nuluk, Pror. U. S. Nat. Mus., XXVI, p. 469, February 3, 1903. Type-docality: Tapanuli Bay, west eoust of Sumatra.

1905. Trichys manotis, Willsk, Natuurkundig Tijdschrift Nelerlantech-Iudiè, LAV 1.268.

\section{bistribution. - Sumbatin.}

Type,-Skin and skull of adult female, collected at Tapmuli lBay, west coast of Sumatra, February 20, 1902, by Dr. W. I. Abbott. Oricrinal No, 1555 .

Diagnostic chardeter.,-Like Trichys lipura from Bormeo, lut with longer ens's, moro augled hamularis, and smaller lachrymal bome.

Colm, - The color of Trichys waerotix diflers in no way from that of T. lijuik.

Eurs. The ous in Trichys metertis are moch longer than they are in $\%$. lipura, and the tips broador and more rounded. Length of an

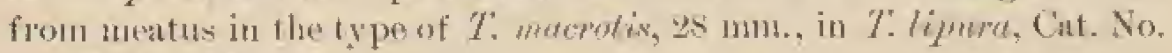
839+1), from Bormeo, 18 mut.

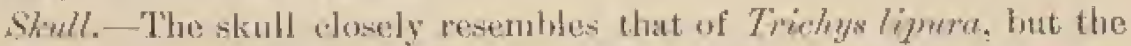
lamular process of the pterygoid bene has a nore pronounced hend or angle on its inferjol aspect, and the tip, insteat of ending in a point burely in contact with the andital halla, is comsiderably thickened and generally in contact with the bulla. 'The lachynal bone is apparently mueh longer in the Bornen animal thun in $T$. matrotis, althongh in many specimens of the latter species the sutures are so obliterated as to render it impossible to determine its exact size. Greatest length of the lachrymal bone in the two Bornean skulls, s and 9 mm. respectively, in four Sumatrus skulls, 4 to $5.5 \mathrm{~mm}$.

Measurements.- See table page 543.

Specimens examined.-Seven, 5 from Tapmuli Bay and 2 from Aru Bay, Sumatra.

\section{RELATIONSHIP OF TH FOUR GENERA OF MALAYAN TORCUPINES.}

The most primitive and unrelated to the others of the Malayan porcupines is the gentu Triflys. Externally Trichys and Atherwass are much alike, but the terminal tuil bristles of Frichys ure peculiat and

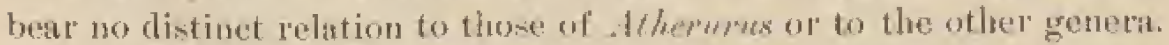
Both Trichys and Athemme have rooted molars, while the molas in the otlue two grenera une rootless. Osteologrally Trichys shows many peculiarities not possessed by the other genem, sweh as the greneral. ized form of the slatl, large number of dorsal rertebre and narrowed

Proe. N. M. vol. $x \times x$ iil $-0,-38$ 
scapulas. Its skull and teeth show resemblances to those of therwhes, and the sacra in the two genera are practically identical. Atherums, althotwh showing strong aftinities to Triclys, appetrs in certain ways to be related to Thecures. Nost of the skeleton of Athemomes is much like that of Thecmm, the only striking difierence being in the lessened number of sacmal and caudal vertebre in Atherwrus, and in the peouliar axis of Theom whe which does not resemble in any way the axis of any of the other three genern. 'T'he cunduh hristles of Athermens might have been derived from those of Themmas, or the reverse. If the cat dal bristles of Atherurus had but one enlargenent, and that more inflated and less flattened, they wond be of the type found in Theoums. Thermondiflers from any of the other three gonera by its peculiar axis. Without its skull and axis it could not bedifferentiated from Acanthom, while if only its sliull were known there would be little excuse for separating it from Atherms, provides no necount were taken of its lootless molars. Acunthim is clearly closely related to /ystrir and less different from that gonus thun it is from Thecueres, Atherans, or Triclys. 'The five genera of Old World porenpines maty be arranged serially thus:

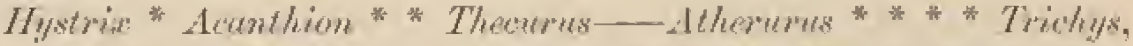
with the most difforent genera at the extremes of the line and the most closely related next to one another. A honk occurs betweou Theraroms and Atherarus so that two subfamilies may be recognized. Mystrie and Acanthiom are evidently direutly and closely related to one another, and Thecurns is certainly nuch closer to them than it is to the Atherme-Trichys group. Whether Ahemes and Trichys aredirenty related to ench other or are only distantly so related through a remote ancestry is difficult to say. The two subfanilies, Hystricinat and Atherurine are sarcely of equal rank, the members of the former being much nore homogeneous than those of the latter. Trichys, ${ }^{a}$ with its generalized structure is evidently the most primitive of the Hystricide and at the opposite end stands Mystrix (Plates IJV, IJV, and LVI, fig. 4), the most specialized, with its peculiar much modified skull aud highly developed quills.

a See Cederblom, Zool. Jalırb., XI, 1897-98, p. 518, and Winge, Jordfundne og nulevende Gnuvere, Lagoa Santa, Brasilien, 1887, pp. 128, 129. 
Tahte of ecternal and crenish measurenents of Matupan poreupines.

\begin{tabular}{|c|c|c|c|c|c|c|c|c|c|}
\hline Nume. & LaneaIity. & Nensulver. & vex uful nge. & $\begin{array}{l}\text { Hend } \\
\text { and } \\
\text { bondy. }\end{array}$ & T'ut1. & $\begin{array}{l}\text { Hind } \\
\text { frist } \\
\text { with } \\
\text { x!luks. }\end{array}$ & $\begin{array}{c}\text { Great- } \\
\text { (wist } \\
\text { letglh } \\
\text { of } \\
\text { skall. }\end{array}$ & $\begin{array}{l}\text { 7ysor } \\
\text { mattio: } \\
\text { widih. }\end{array}$ & 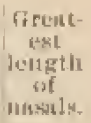 \\
\hline $\begin{array}{l}\text { Acrinthion joses } \\
\text { nforem. }\end{array}$ & JAVR $Y \ldots \ldots$ & in 2hosis & Olis.. & $\lim _{6 \infty}$ & $\begin{array}{c}m m w_{+} \\
n[7 t\end{array}$ & $\begin{array}{c}\text { mime. } \\
\text { lo } 95\end{array}$ & $\begin{array}{l}\text { Nown. } \\
195\end{array}$ & min. & $\begin{array}{l}\text { MMA. } \\
\text { PNG.4. }\end{array}$ \\
\hline 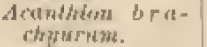 & $\begin{array}{l}\text { Cha mpeng. } \\
\text { Telatkeritn. }\end{array}$ & $01210 \times 0$ & Femule, old .. & $d 725$ & 11.40 & 6112.5 5 & 150 & & \\
\hline low......... & $\begin{array}{l}\text { Trang, Lower } \\
\text { Sintil. }\end{array}$ & - 58631 & Male, mulult... & 2471 & if 114 & 6.55 & 112.5 & (51) & 5.3 .4 \\
\hline $\begin{array}{l}10, \ldots . . \\
10, \ldots .\end{array}$ & $\ldots$. & $\begin{array}{l}n-83514 \\
4946 \%\end{array}$ & $\begin{array}{l}\text { Futuale, aluit. } \\
\text { Fobtug h }\end{array}$ & 4635 & S Es & ege & 13 & 60,6 & 58 \\
\hline Dow..... & . . alio . . . . . . & c s3ingi & Yostug, onule il & a 44 & $\operatorname{arst}$ & $\mid c+40$ & $\begin{array}{l}162 \\
110\end{array}$ & (5) & $\begin{array}{l}734,5 \\
12\end{array}$ \\
\hline 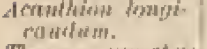 & $\begin{array}{l}\text { Aru Huy, 5u- } \\
\text { motma. }\end{array}$ & mStHIS1 & ..... $10, \ldots+\ldots+$ & ablis & of 69.5 & 172 & $1 \mathrm{ths}$ & 65 & 11.5 \\
\hline Thenerux at matrer? & .+... & c) 113434 & Male, olel & of 4,40 & 1100 & तi 70 & 1018 & 74 & 29,6 \\
\hline$D_{1} \mathrm{H}_{1} \ldots \ldots \ldots \ldots$ & {$\left[\begin{array}{c}\ldots 110 \\
\ldots\end{array}\right.$} & 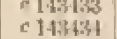 & $\ldots . .8$ & if 45,5 & $\begin{array}{rl}d & \pm 0 \\
d 1 & 100\end{array}$ & 470 & $7011_{2}^{3}, 3$ & Sti. I & $319=$ \\
\hline Jlo............ & $\ldots$. do & a 14i3t3 & Fenale, olif... & $\sqrt{4+455}$ & $\begin{array}{l}2110 \\
0160\end{array}$ & $\begin{array}{l}\text { int } \\
\text { if } 645\end{array}$ & $\begin{array}{l}105.4 \\
16,5\end{array}$ & $\begin{array}{l}\text { fal } \\
\pm 0.1\end{array}$ & 99.7 \\
\hline$\ldots \ldots \ldots+1$ & ....do......... & 0143128 & $\ldots+40$ & a 5025 & ता & 173 & 100.3 & 543.2 & 90 \\
\hline . & $\ldots \ldots$ do ... & c 143139 & ato do & is 5000 & 130 & $d 76$ & 约. 6 & 55 & $2 \pi, 5$ \\
\hline Ilo. & ..... do ... & 19470 & Male, old . & 4440 & 6110 & 1.70 & 97.6 & 53 & 3 \\
\hline 141. & $=\ldots$.110 ... & y 14341 & Mule, wrult.... & d ISW & 490 & & 95.7 & 52.5 & 30.1 \\
\hline Itri . & $\ldots \ldots$ didn ... & $+1181 ; 0$ & $\ldots . .$. rto .......... & rt 5030 & $\$ 110$ & 75 & 10\%, ti & 54.2 & $\$ 13$ \\
\hline Tho: $=$ & -...drin ... & (c) 1.13134 & Finnle, adoult & $d+46$ & al 1136 & 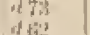 & $10 \geq 2,6$ & 50,13 & $\frac{140}{40}$ \\
\hline & ,..... & Q Thtar & yourig & $n+50$ & TU & $T_{4,2}$ & 46,1 & 16.3 & 27 \\
\hline 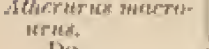 & $\begin{array}{l}\text { Tromb, LAM ET } \\
\text { silatil. }\end{array}$ & 11 -19448 & old $\ldots \ldots \ldots$ & $t+140$ & $1+210$ & 470 & 101.0 & 15.2 & 28,2 \\
\hline Do. & $\{\ldots \ldots t$ & c. 1.1133 & fermale, , ild ... & int & et 229 & - $\mathbb{B A}_{1}$ & 99.2 & 17.7 & $2 t_{1}+2$ \\
\hline [ Jo & .... adten ... & $+84+510$ & {$[e, 14]$ tnli. } & $18.1 \times 2$ & at:203 & efti & 1 & -1.t. 7 & 27.4 \\
\hline flo ............... & 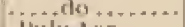 & e $514: 32$ & nok. & $=170$ & N136 & o t6in & 191,9 & H.? & 25.0 \\
\hline 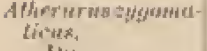 & J'ulis dor....... & $11^{\prime}+132$ & Mnle, old .... & af 185 & rif bin & $=61$ & 16.5 & $-1 b, 4$ & 24.3 \\
\hline$I_{i n}$ & {$[\ldots . . r$} & ril & 14 & $=4510$ & At sol & ran & 9y. 4 & 拈. & 77. \\
\hline 100 . & $\mid-\cdots+n$ & ef 112409 & Fein & $452\}$ & 12001 & $\therefore$ in & X & 4 & 25. Al \\
\hline then+mat & F... & $=1124: 4$ & Fismale & 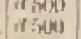 & $\begin{array}{l}\text { id } 145 \\
\text { dit } 46\end{array}$ & C the & $30, \frac{7}{8}$ & $\begin{array}{l}\text { 45. } 8 \\
\text { (10.3 } 3\end{array}$ & $\begin{array}{l}20.6 \\
14.1\end{array}$ \\
\hline (....... & . . s rlo........ & a towne & Ailinli......... & $b(4)$ & 3175 & U 15 & 94.4 & 46.1 & 36.5 \\
\hline Dis .... & $\ldots$. & e II난-IIK & Fe min il e. & at 170 & d 190 & $=$ Pi2 & 8. 4 & 11.1 & 14.1 \\
\hline $130 \ldots+\ldots+\ldots$ & $\ldots$ d & c 112425 & Nat & ins 470 & st 170 & in 6 , & 86. I & 11 & 21 \\
\hline $\begin{array}{l}\text { dherneris erta. } \\
\text { torkh. }\end{array}$ & Pulo Terubal. & :j 125971 & Male, adull ... & $1+110$ & if 110 & < 12 & 93.1 & $4 b, 7$ & 23 \\
\hline Trichyn lipurat ... & $\begin{array}{l}\text { Mount ball- } \\
\text { knta, Bormero }\end{array}$ & - 4410 & $\begin{array}{l}\text { Mule, liearly } \\
\text { ndint. }\end{array}$ & $e 4(-0)$ & $<175$ & & \$3.7 & 13,8 & 4) 5 \\
\hline rnich & $\begin{array}{l}\text { Hritdeh North } \\
\text { [Borneo. }\end{array}$ & 山制视的 & drlult .... & 380 & 10200 & $b f_{5}$ & $43,-1$ & $\$$ & 27.1 \\
\hline Tricky macrotis & $\begin{array}{l}\text { Tejouts]f Jaty, } \\
\text { sumatrs. }\end{array}$ & $e 11.459$ & Nale, oll & $1+10$ & d 180 & $=6 \mathrm{H}$ & 82.7 & 4 & 26.8 \\
\hline 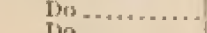 & ...... d lo... & - $11+6490$ & Male, aulult & त) 115 & If 18 i & -62 & 83.4 & 1.4. 3 & 27.4 \\
\hline Do, & $=-\ldots$ - d lo $=-$ & C11.44h & Feminge oled & df fin & 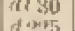 & 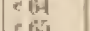 & & $1 \pm 4$ & $20=$ \\
\hline Do & $\ldots$, & क11.1491 & Fumale isinili. & $d+12 z$ & at 19.5 & in & 82.8 & $\begin{array}{l}+4.5 \\
45\end{array}$ & 25,0 \\
\hline & Ari 13ny, sL. & c 113141 & $\ldots . . . d 0 \ldots . . .$. & ditis & it 200 & $=60$ & 74 & f'. 8 & 22,4 \\
\hline Do. & $\ldots$ & c 1.H40 & $\begin{array}{l}\text { Feumble, firi- } \\
\text { musure. }\end{array}$ & 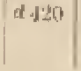 & $\| \geqslant 0$ & of (a) & 79.7 & $14+2$ & $2: 7$ \\
\hline
\end{tabular}

asteleton.

Hatimiterl from skelelors.

c Skin and risull.

i Collectores rindisurements.

- Measmrest from gkin.

f'T'nll injuret.

0 siskili mily.

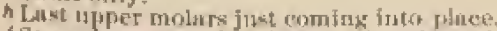

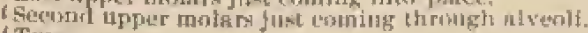

1Ty]p:

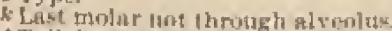

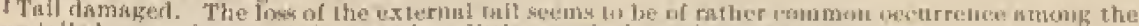

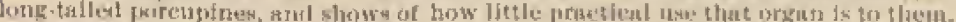

m Latimated from mourter skfi. 


\section{FAPIANATION OF PLATES.}

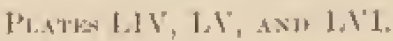

Thorsal, lateral, and vetulral viewa of skulle of Glal World portapines. All figures wre. half natural size.

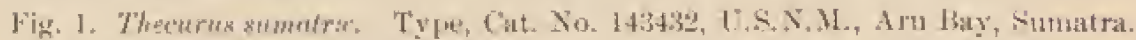

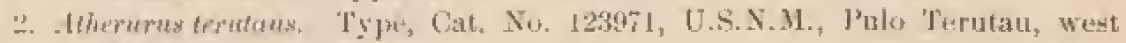
coast Malay P'eninsula.

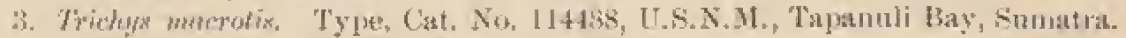

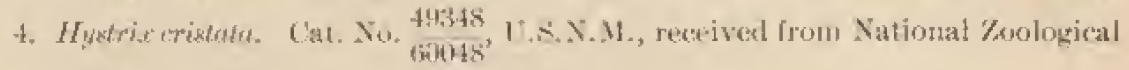
P'ark.

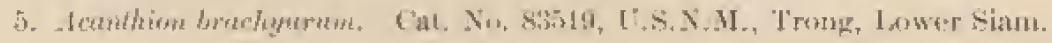

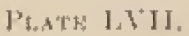

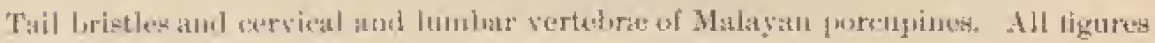
threaforiths natural size.

Ligr. 1. Tail bristle of atomither.

2. Tail briatles of Theonew.

3. Tail bristle of dethererex.

4. Tuil bristle: of Trithos.

5). Axis or secolad eervical vertelura of Trichys.

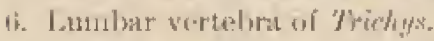

7. Axis ur secomal aervieal vertebra of . Mheruras

8. Lomblar vertebra of . Whowrowe.

4. Ixis or secoud entical verleitra of theruras.

11. L.umbar verwebra af Therentas.

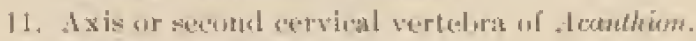

12. Lambar vertebra of fonthion. 


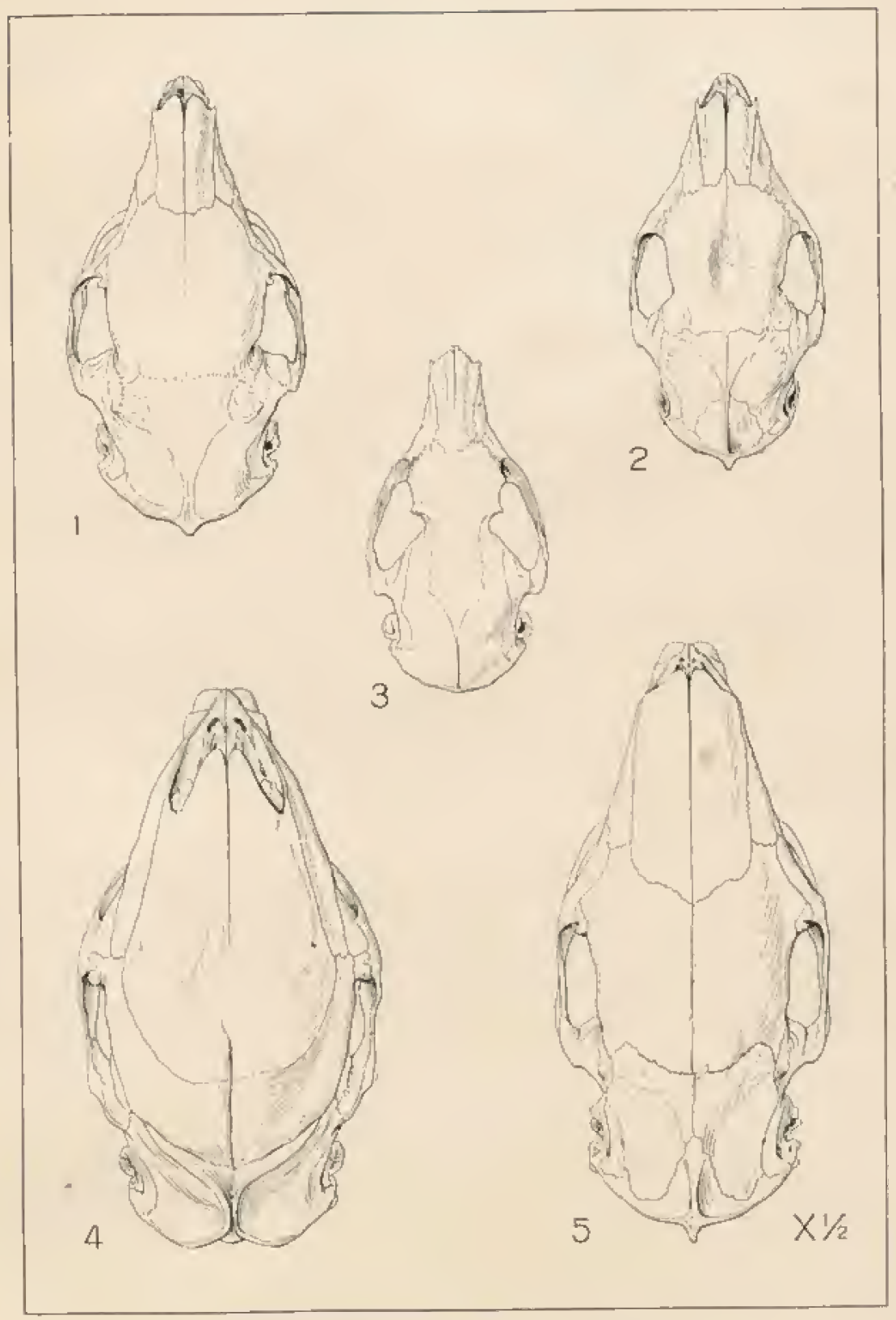

SKULls of OLD WORLD PORCupines.

FOH EXPLAMATION OF PLATE GEE PAGE 594 



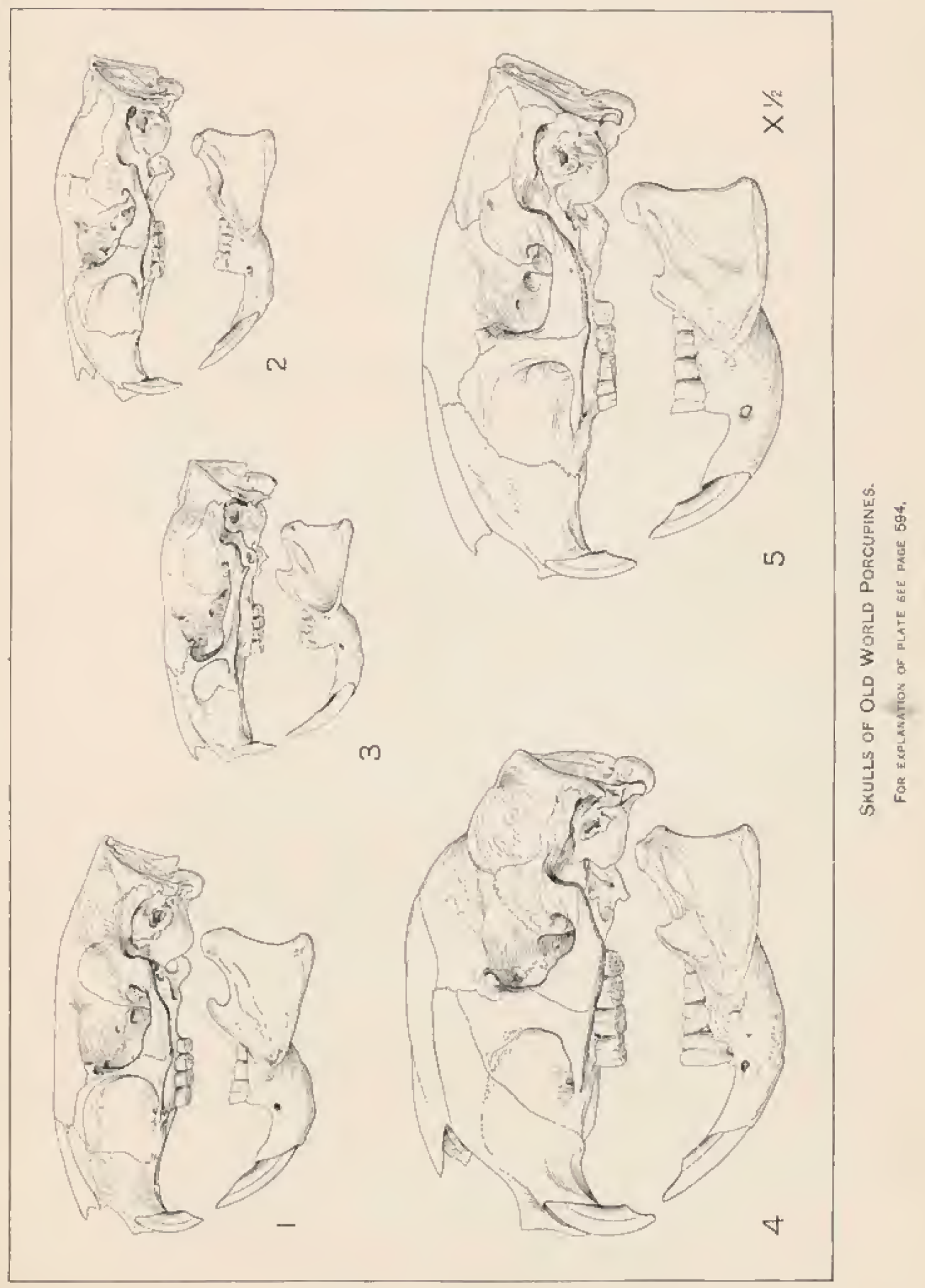





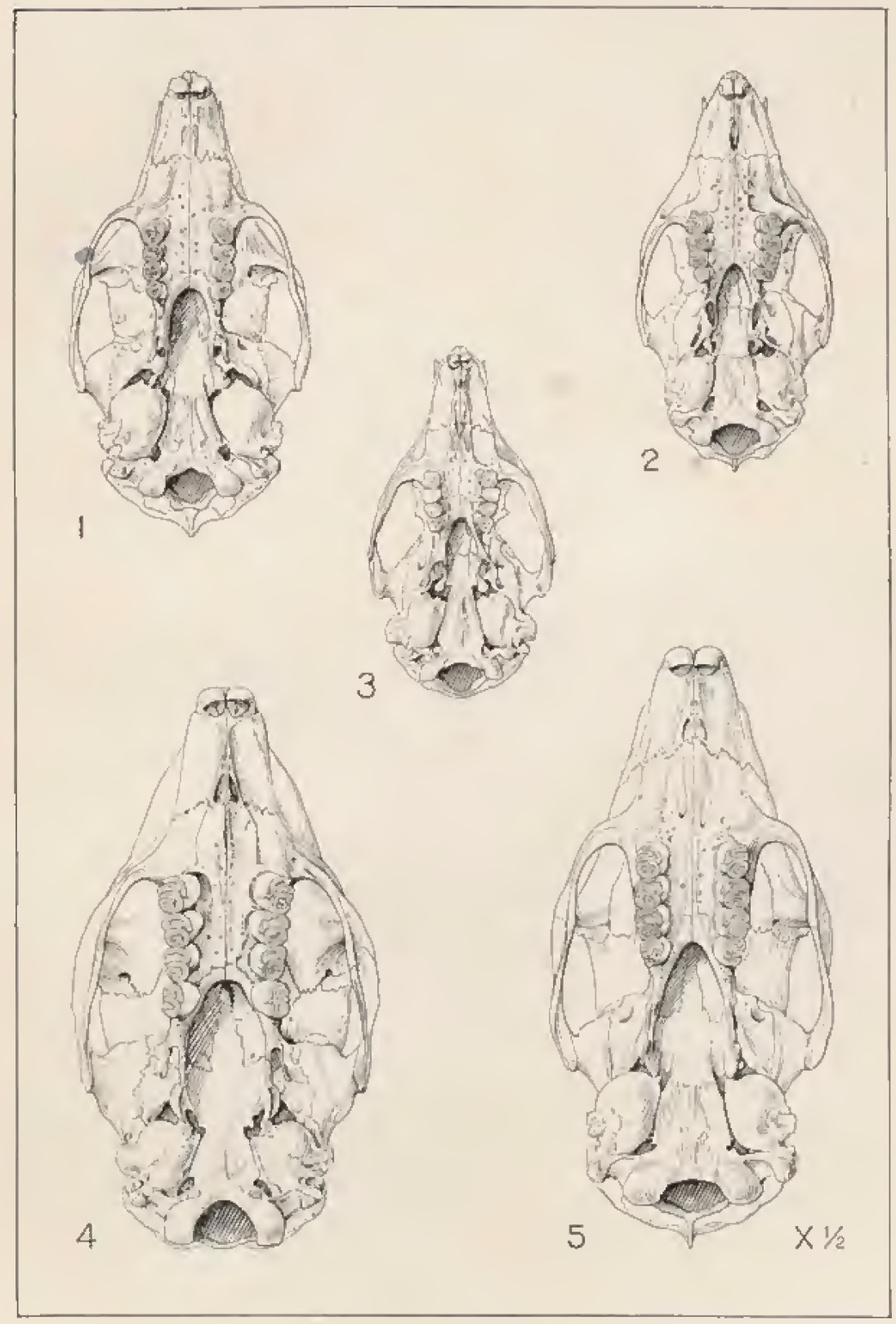

SKULLS OF OLD WORLD FORCUPINES.

Fóf ExPLAMATIOK OF PLATE SEE PhoE 594. 



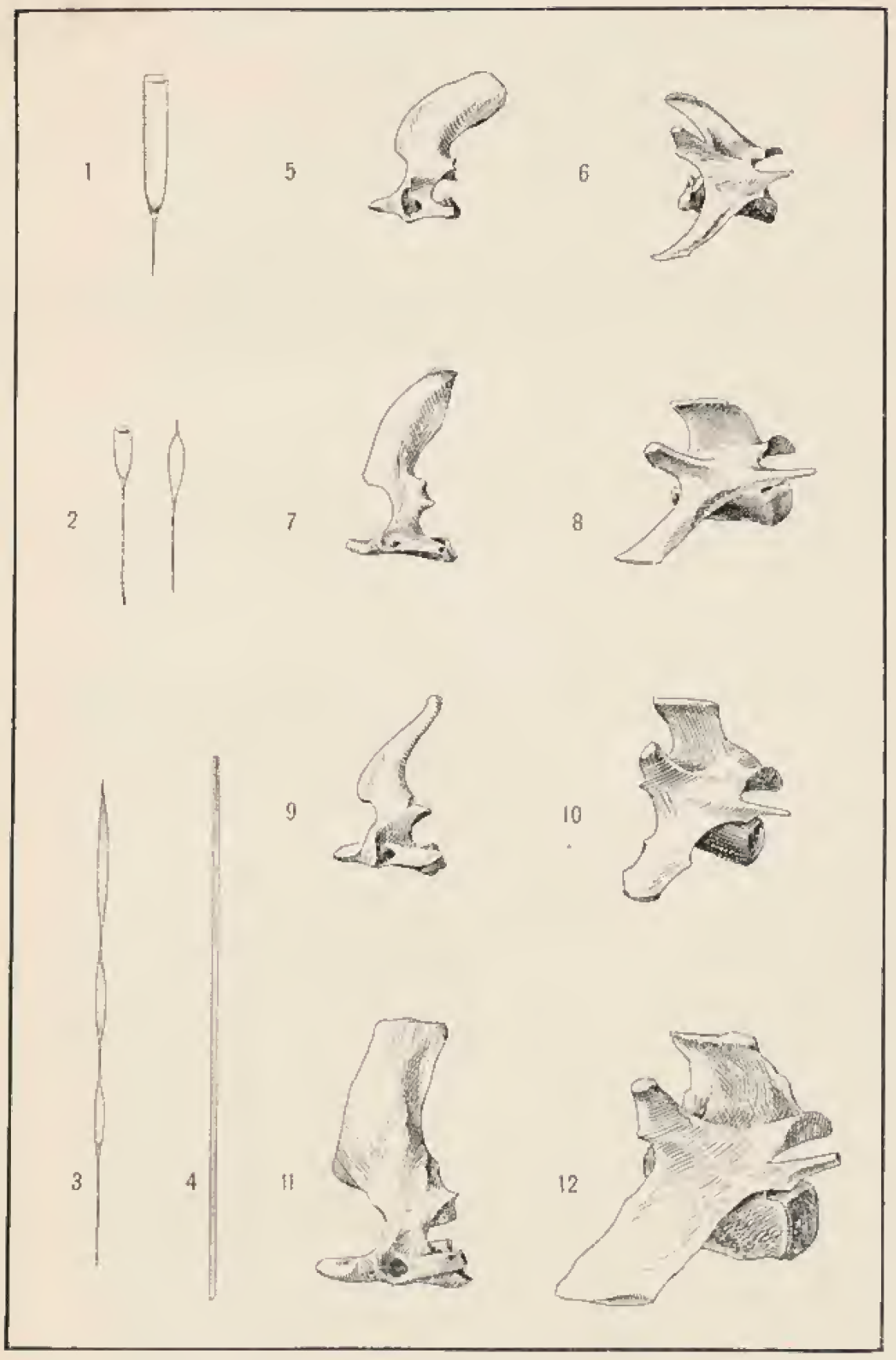

Tall Baistles and Vertebrae of Malayan Porcupines. FOR EXPLAMATION OF PLATE BEE PAGE 594. 




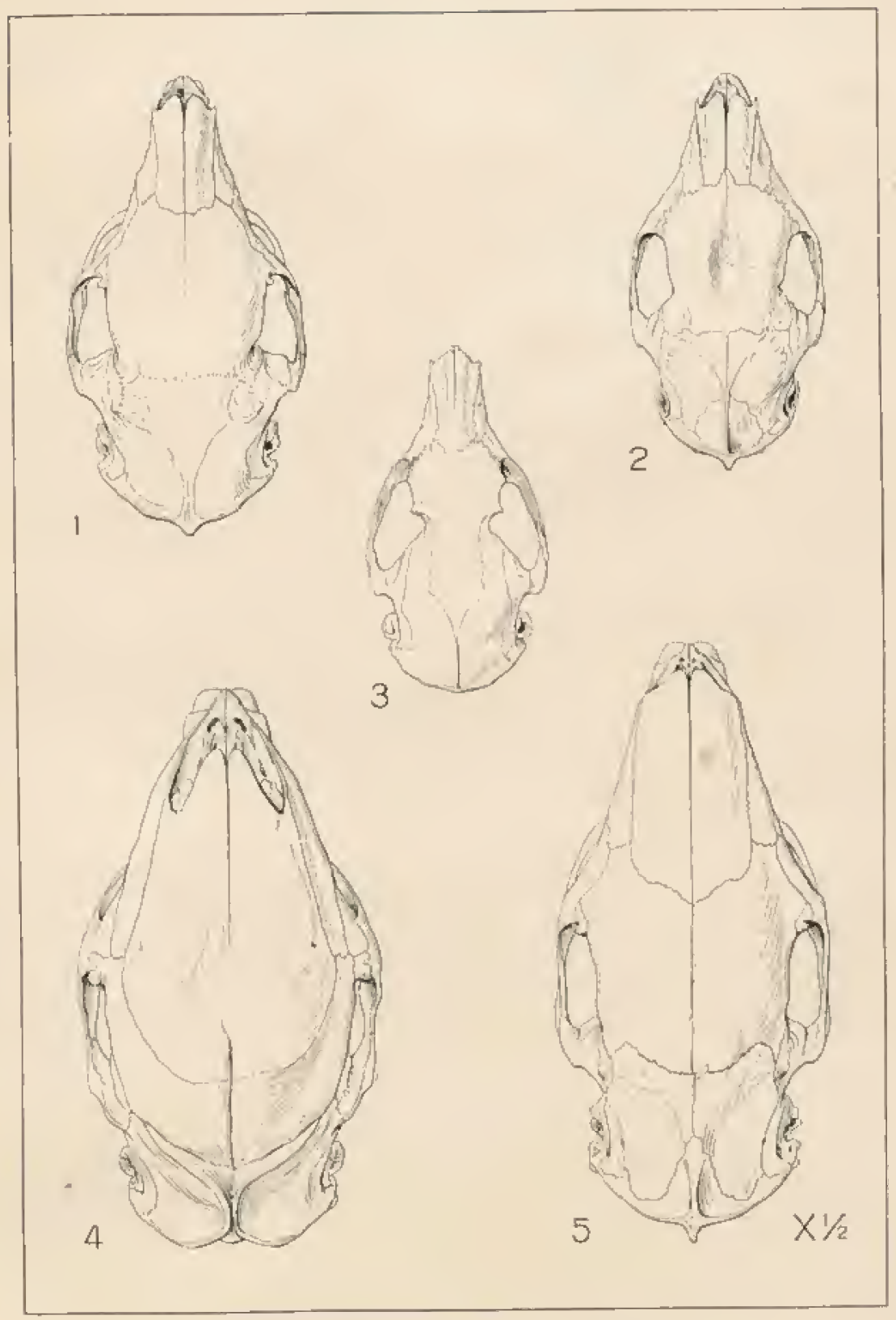

SKULls of OLD WORLD PORCupines.

FOH EXPLAMATION OF PLATE GEE PAGE 594 


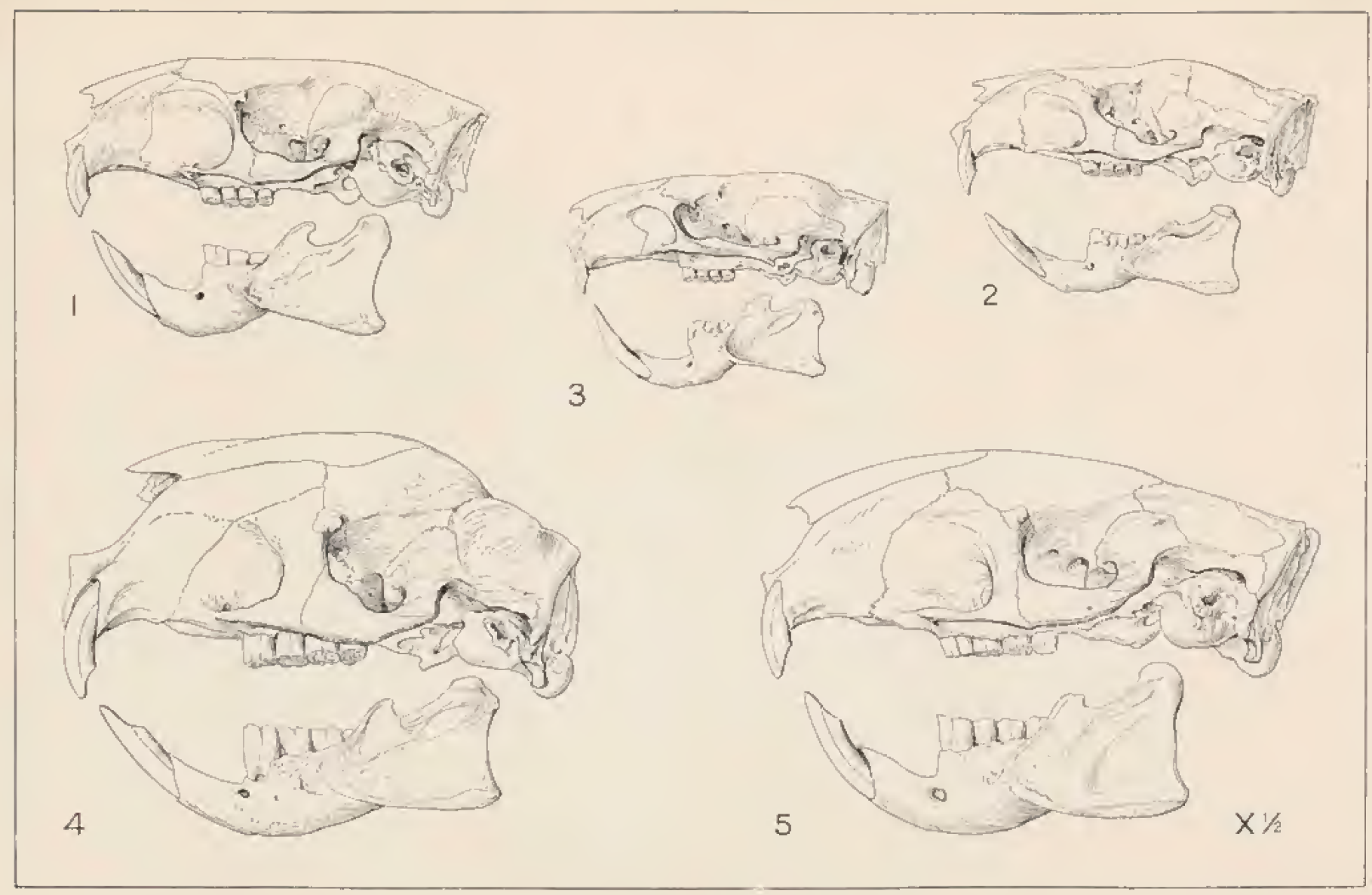

SKULLS OF OLo WOHLD PoRCUPINES.

FOM Explamation OF FLATE gEE FhaE 594. 


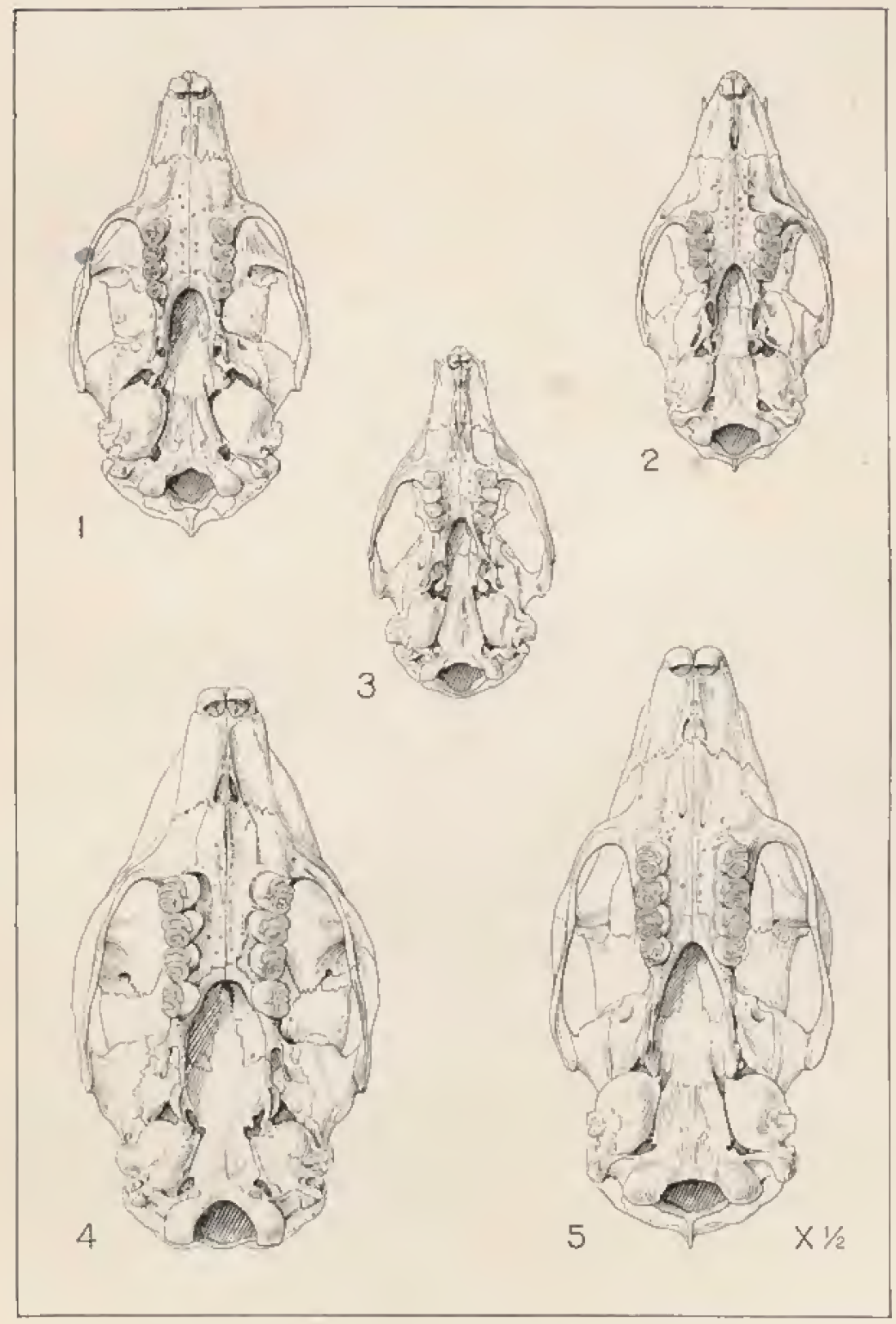

SKULLS OF OLD WORLD FORCUPINES.

Fóf ExPLAMATIOK OF PLATE SEE PhoE 594. 


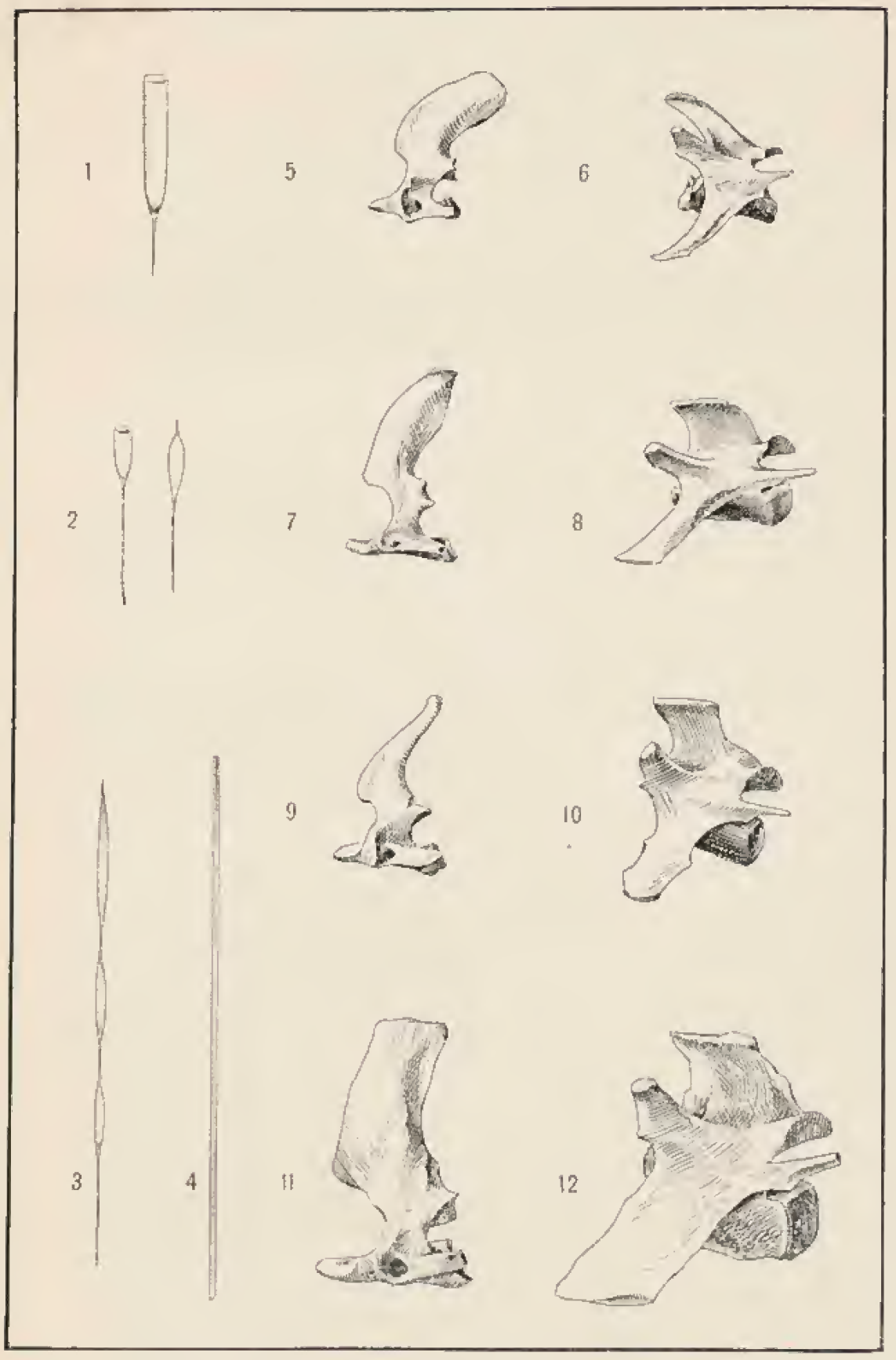

Tall Baistles and Vertebrae of Malayan Porcupines. FOR EXPLAMATION OF PLATE BEE PAGE 594. 